Provided for non-commercial research and education use. Not for reproduction, distribution or commercial use.

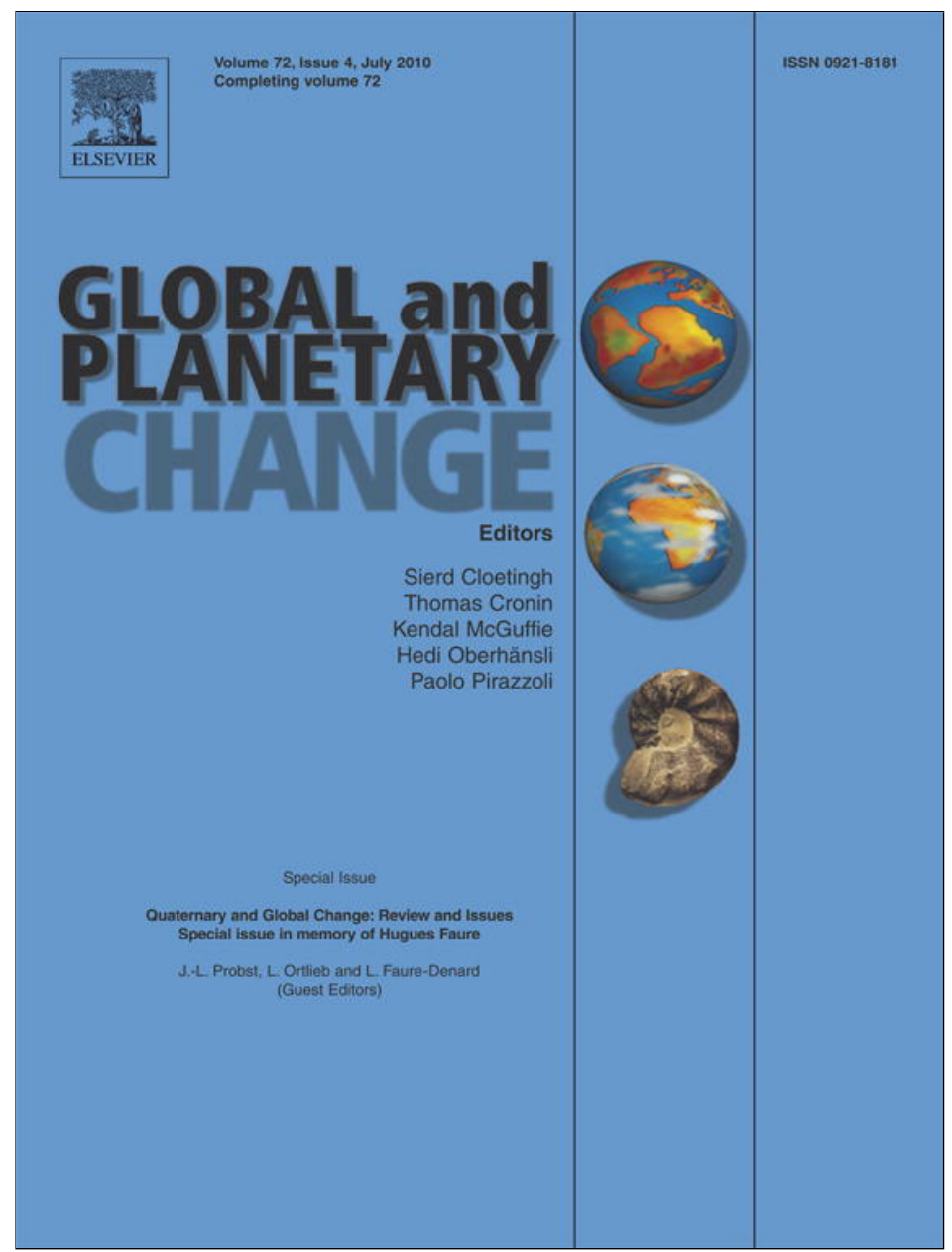

This article appeared in a journal published by Elsevier. The attached copy is furnished to the author for internal non-commercial research and education use, including for instruction at the authors institution and sharing with colleagues.

Other uses, including reproduction and distribution, or selling or licensing copies, or posting to personal, institutional or third party websites are prohibited.

In most cases authors are permitted to post their version of the article (e.g. in Word or Tex form) to their personal website or institutional repository. Authors requiring further information regarding Elsevier's archiving and manuscript policies are encouraged to visit:

http://www.elsevier.com/copyright 


\title{
Climate change and human occupation in the Southern Arabian lowlands during the last deglaciation and the Holocene
}

\author{
Anne-Marie Lézine ${ }^{\mathrm{a}, *}$, Christian Robert ${ }^{\mathrm{b}}$, Serge Cleuziou ${ }^{\mathrm{c}}$, Marie-Louise Inizan ${ }^{\mathrm{d}}$, Frank Braemer ${ }^{\mathrm{e}}$, \\ Jean-François Saliège $^{\mathrm{f}}$, Florence Sylvestre ${ }^{\mathrm{b}}$, Jean-Jacques Tiercelin ${ }^{\mathrm{g}}$, Rémy Crassard ${ }^{\mathrm{c}}$, Sophie Méry ${ }^{\mathrm{c}}$, \\ Vincent Charpentier ${ }^{c}$, Tara Steimer-Herbet ${ }^{\mathrm{h}}$ \\ a UMR 1572, Laboratoire des Sciences du Climat et de l'Environnement (LSCE), Orme des Merisiers, 91191 Gif-sur-Yvette cedex, France \\ b UMR6635, Centre européen de recherche et d'enseignement de géosciences de l'environnement (CEREGE) Europôle méditerranéen de l'Arbois, BP 8013545 Aix-en-Provence cedex 4, France \\ c UMR7041, Archéologies et Sciences de l'Antiquité (ArScAn) Université Paris X, Maison René Ginouvès, 21 allée de l'université F-92023 Nanterre cedex, France \\ d UMR7055, Préhistoire et Technologie Université Paris X. Maison René Ginouvès, 21, allée de l'université F-92023 Nanterre cedex, France \\ e UMR6130, Centre d'Études Préhistoire, Antiquité, Moyen-Age (CEPAM) Centre national de la recherche scientifique, Sophia Antipolis, 250 Rue Albert Einstein, F-06560 Valbonne, France \\ ${ }^{\mathrm{f}}$ UMR7159, Laboratoire d'Océanographie et du Climat: Expérimentations et Approches Numériques (LOCEAN) Université Pierre et Marie Curie, case 100, 4 place Jussieu, 75252 Paris cedex 05, France \\ g UMR6118, Géosciences Rennes, bat. 15, campus de Beaulieu, 263 Av du général Leclerc, BP 7420535042 Rennes cedex, France \\ ${ }^{\mathrm{h}}$ Institut Français du Proche Orient (IFPO), Jisr al-Abiad, BP 3694, Damas, Syria
}

\section{A R T I C L E I N F O}

\section{Article history:}

Accepted 13 December 2009

Available online 18 January 2010

\section{Keywords:}

paleohydrology

palynology

clay mineralogy

human settlements

Yemen

Oman

Arabian lowlands

Holocene

\begin{abstract}
A B S T R A C T
Paleohydrological and archaeological evidence from the Southern and South-Eastern Arabian Peninsula reveal strong relations between phases of human settlements and climate change linked to the Indian monsoon system. During the early to mid-Holocene, large fresh-water lakes extended in the lowland deserts of Ramlat as-Sab'atayn (Yemen) and Wahiba Sands (Oman), which were very similar to those occurring in the North, in the Rub' al-Khali (Saudi Arabia), at that time. Many archaeological sites, characterized by scattered stone artefacts, ostrich-eggshells and bones around hearths, are related to this lacustrine phase, which culminated around $10000-8000 \mathrm{cal}$ yr B.P. in the lowland deserts before the lakes progressively dried up. The last record of fresh-water bodies' extensions date back $7300 \mathrm{cal}$ yr B.P. at Shabwa (Yemen) and 7500 cal yr B.P. at al-Haid (Oman). Then, fresh-water was probably available only from seasonal run-off from adjacent highlands, where paleolakes persisted into the late Holocene. Dry climate conditions in the inland desert of Yemen during the late Holocene coincide with a phase of intensive human inhabitation as testified by development of irrigation in the piedmontane areas, numerous necropolises of built collective burials and houses.
\end{abstract}

(C) 2010 Elsevier B.V. All rights reserved.

\section{Introduction}

During the Holocene, tropical deserts of Africa and Arabia experienced strong climate variations leading to the development of fresh-water lakes and the setting of Neolithic populations in areas which are now very arid and inhospitable. Although relations between man and environment are now well documented in northern Africa at both regional (e.g., Hoelzmann et al., 2001) and continental scales (Petit-Maire et al., 1993), the tropical desert of Arabia is still poorly investigated. There, archaeological data older than the 6th millennium B.P. are scarce, but excavations and archaeological surveys have demonstrated an early Holocene human occupation at the foot of the Omani highlands (Uerpmann et al., 2000), near the littoral of the Indian ocean (Charpentier

\footnotetext{
* Corresponding author.

E-mail address: anne-marie.lezine@lsce.ipsl.fr (A.-M. Lézine).
}

et al., 2000), or in the inland desert of Yemen, the Ramalt as-Sab'atayn (Cleuziou et al., 1992; Inizan et al., 1998). Widespread development of complex cultures after the Early Bronze Age when agriculture, metallurgy, pottery and economic exchanges develop in Yemen (e.g. Braemer et al., 2001) and Oman (in Cleuziou, 2005) deserts as climate conditions become drier (e.g., Fleitman et al., 2003) lead to several questions: Do the occupation phases and cultures correlate with climate variations and how? How did the environmental resources (fresh-water and plants) change with climate?

The aim of this article is to review our current knowledge of manclimate relations in the lowlands of Southern and Eastern Arabia (Yemen, Oman) during the Holocene using recent studies carried out in the frame of the French Research Programme, ECLIPSE. Data comprise mineralogy, pollen, isotope and diatoms according to the sites and archaeological findings with the objective to place the history of human occupation in a reliable climatic and environmental context. Palaeoenvironmental data from two selected paleolakes in the Yemen highlands are also discussed. 


\section{Environmental setting}

The climate of Southern Arabia is strongly influenced by the summer migration of the intertropical convergence zone (ITCZ) and the associated Indian monsoon rainfall belt (Fig. 1). In summer southwesterly surface winds carry moisture from the Southern Indian Ocean along the Arabian coast but do not penetrate far northwards into Southern Arabia. The mean annual rainfall rapidly decreases from the coast to the interior and from the mountains to the lowlands. The maximum rainfall is recorded in the highlands of Yemen (about $1000 \mathrm{~mm}$ ) and the minimum in the inland desert of the Ramlat asSab'atayn $(22 \mathrm{~mm})$; the coastal stations of Aden and Salalah recording about 57 and $83 \mathrm{~mm}$ of annual rainfall, respectively. SW monsoon fluxes also decrease to the North-East and barely penetrate the Gulf of Oman. This area is characterized by north-westerly winds throughout the year. In winter, southward penetration of Mediterranean cyclonic depressions through Mesopotamia and the Persian Gulf corridor between the Zagros Mountains in Iran and the Jebel al Akhdar range in northern Oman, is responsible for noticeable precipitation: $350 \mathrm{~mm}$ annual rainfall at Saiq at 1755 malt in the Jebel al Akhdar, and about $90 \mathrm{~mm}$ at Muscat, Sur and Ras al-Hadd near the coast. West of this corridor strong, northeasterly winds in winter intensify dry conditions and transport high quantities of dust to the ocean.

Mean temperature varies from about $26^{\circ} \mathrm{C}$ in the coastal regions under the monsoonal influence to $28^{\circ} \mathrm{C}$, with temperature falling with altitude from about $0.6^{\circ} \mathrm{C}$ per $100 \mathrm{~m}$ elevation in the mountains of Yemen and Oman.

The vegetation of the southern part of the Arabian Peninsula, which receives tropical summer rain is mainly composed of AcaciaCommiphora xerophytic, "Somalia-Masai", communities, which develop mainly in the foothills or near seasonal river beds, whereas open desert shrublands are characterized by Calligonum, Cyperus, Dipterygium and Tribulus growing on sand dunes (Ghazanfar and Fisher, 1998). An eastern community type with Prosopis cineraria of "SudanoMakranian" affinity is present on the eastern side of the Arabian Peninsula, where precipitation occurs in winter. The montane vegetation shows a distinct altitudinal distribution with Acacia woodlands at lower elevation, semi-evergreen (sclerophyllous) woodlands, and evergreen needle-leaved woodlands with Olea and Juniperus at higher elevation of the highlands. In the inland and littoral sebkhas, where saline conditions prevail, the vegetation mostly consists of Chenopodiaceae herbaceous communities whereas Avicennia marina occurs in mangroves.

\section{Modern pollen data}

Fifty-nine soil surface samples taken along a latitudinal transect through the Rub' al-Khali sand sea, from the Ramlat as-Sab'atayn to the South to the Iraq coastal areas to the North, and along an altitudinal transect from the littoral to $2000 \mathrm{~m}$ alt in Oman illustrate the pollen signature of major Arabian ecosystems (Fig. 2; Table 1). The latitudinal transect, combining regional studies from Lézine et al. (1998), Bonnefille and Riollet (1988) and El-Moslimany (1983) has been detailed in Lézine et al. (1998) (Table 1) and is summarized here:

(1) Lowland areas from Yemen and Saudi Arabia under SW monsoon influence of summer precipitation are characterized by high amount of pollen grains from herbaceous populations with Tribulus (maximum $=12 \%$ ), Dipterygium-type glaucum (17\%), Calligonum (31\%), Cyperaceae (79\%) and Poaceae (25\%).

(2) Cyperaceae and Calligonum dominate in the Rub' al-Khali sand sea in association with Limeum-type (10\%), whereas Aerva lanata-type dominates in the Ramlat as-Sab'atayn with $19 \%$.

(3) Tropical trees, mainly Acacia and Commiphora are locally present in the southernmost samples from Yemen with a total percentage reaching up to $15 \%$.

(4) The northern limit of the monsoon influence closely corresponds to the disappearance of the tropical plants from the pollen diagram and their replacement by Plantago (38\%), Asteraceae (16\%) and Cichorieae (28\%). The dominance of Chenopodiaceae-Amaranthaceae $(99 \%)$ pollen types indicates widespread dry, saline, soil conditions.

The altitudinal transect shows continuous occurrence in significant amounts of Prosopis-type cineraria (9\%), which characterize the lowlands of Eastern Oman. This pollen-type is associated with Acacia (13\%) and abundant herbs, mainly Asteraceae (33\%), Chenopodiaceae-Amaranthaceae (47\%), Cyperaceae (37\%) and Poaceae (64\%). It disappears at higher altitudes in the Jebel al Akhdar, where it is replaced by Acacia, associated with Dodonaea viscosa (7\%) then by Olea europea-type (31\%) above $1100 \mathrm{~m}$ alt. Finally, the near shore samples from relict mangroves of the Oman Gulf (Sur, Quryat, Kwar al Jaramah) (Lézine et al., 2002) record the presence of Avicennia with continuous low pollen values (6\%).

\section{The Holocene sedimentary sequences}

Five lacustrine sedimentary sequences of Holocene age ranging from $12000 \mathrm{cal}$ B.P. to 5000 cal. B.P. were detailed for mineralogical
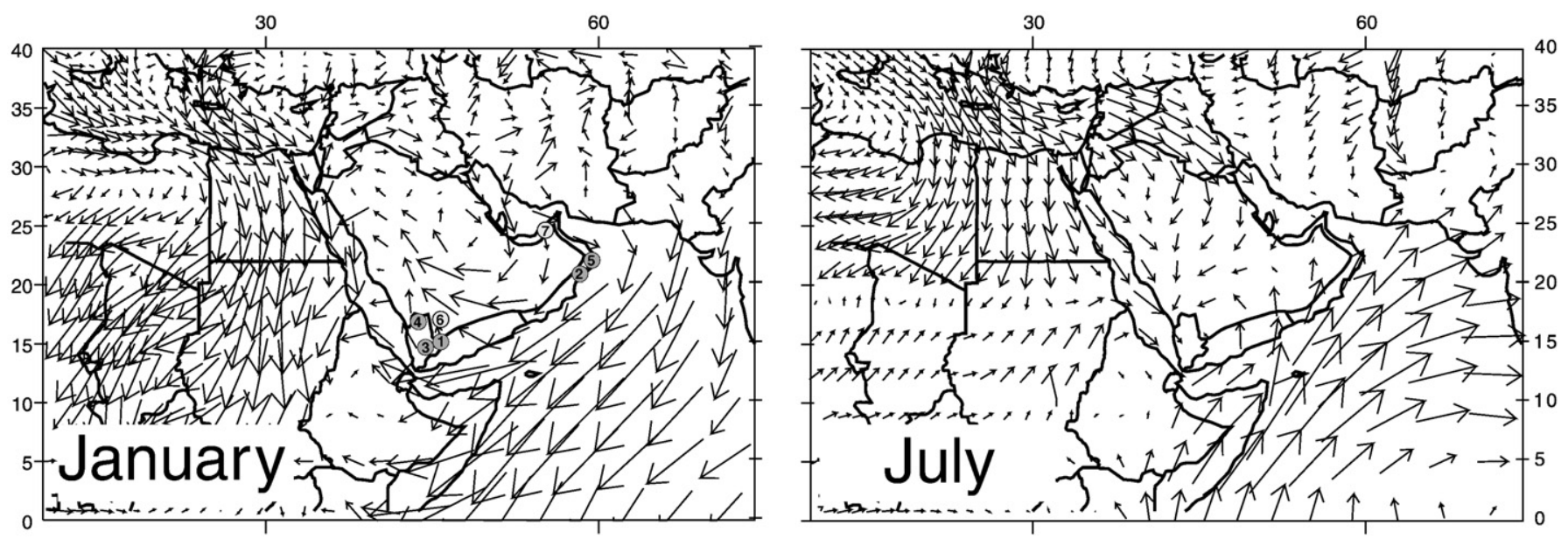

Fig. 1. Surface wind trajectories in winter (on the left) and summer (on the right) over Arabia and surrounding areas. Paleohydrological/Palynological sites cited in the text are located at 1: al-Hawa, 2: al-Haid, 3: Rada, 4: Saada, 5: Suwayh, 6: Mundafan, and 7: At Awafi. 
analyses and chronology. They were recovered from the lowland sand seas of Ramlat as-Sab'atayn in central Yemen (al-Hawa) and of the Wahibah sands in Southern Oman (al-Haid), and from the Yemen highlands (Rada and Saada). Only two sequences were favourable to pollen (al-Hawa) and diatom (Rada) analyses.

\subsection{Methods}

\subsubsection{Bulk and clay mineralogy}

The sedimentary sequences of al-Hawa, al-Haid, Rada, Saada 1 and Saada 3 were sampled at 1 to $5 \mathrm{~cm}$ interval for bulk and clay mineral

South-North latitudinal transect - Lowlands of Yemen, Saudi Arabia, Qatar, Koweit, Irak

(El-Moslimany,1983; Bonnefille and Riollet,1988, Lézine et al.,1998)

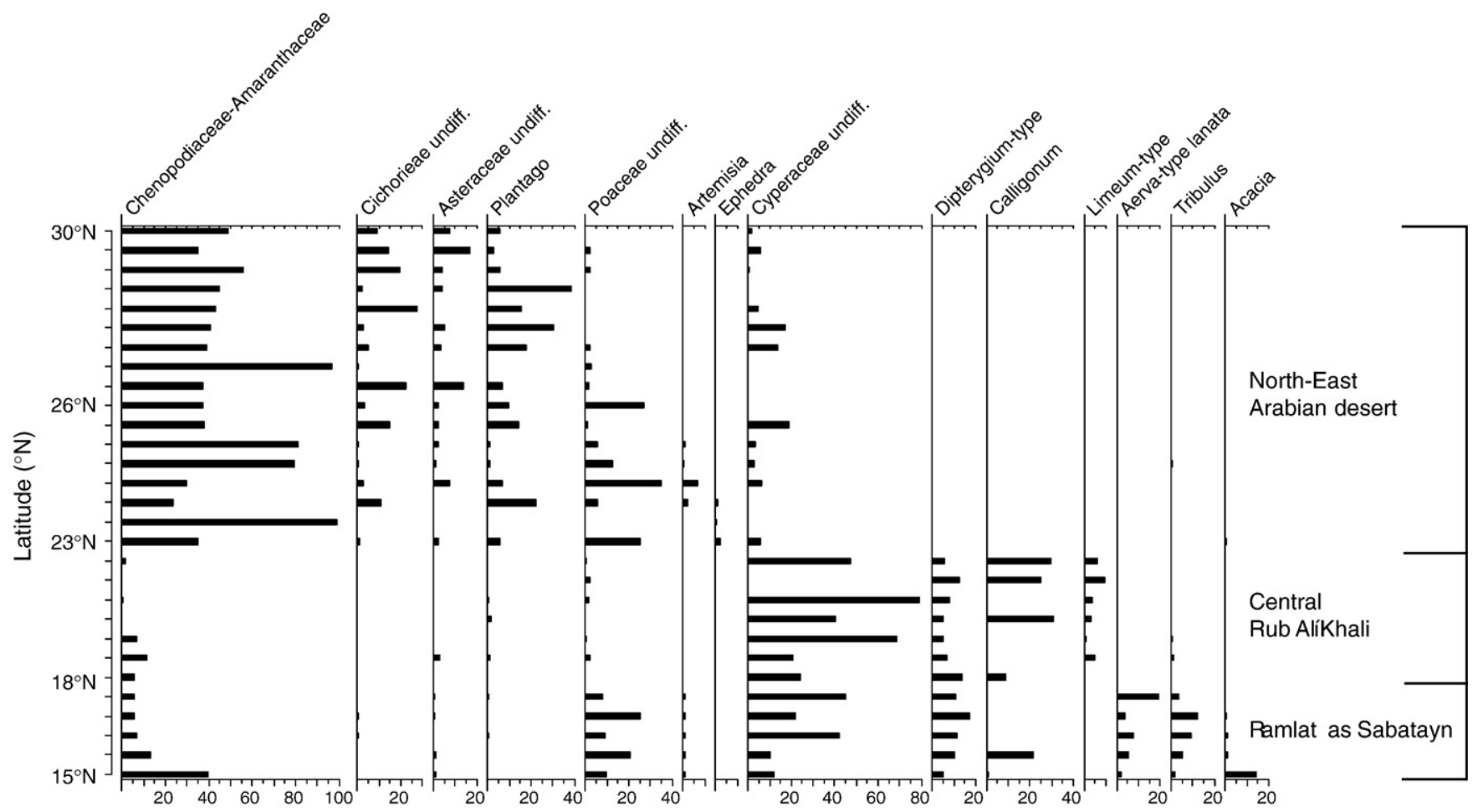

Altitudinal transect-Eastern Arabian Peninsula (Oman) (Lézine et al., 2002; this study)

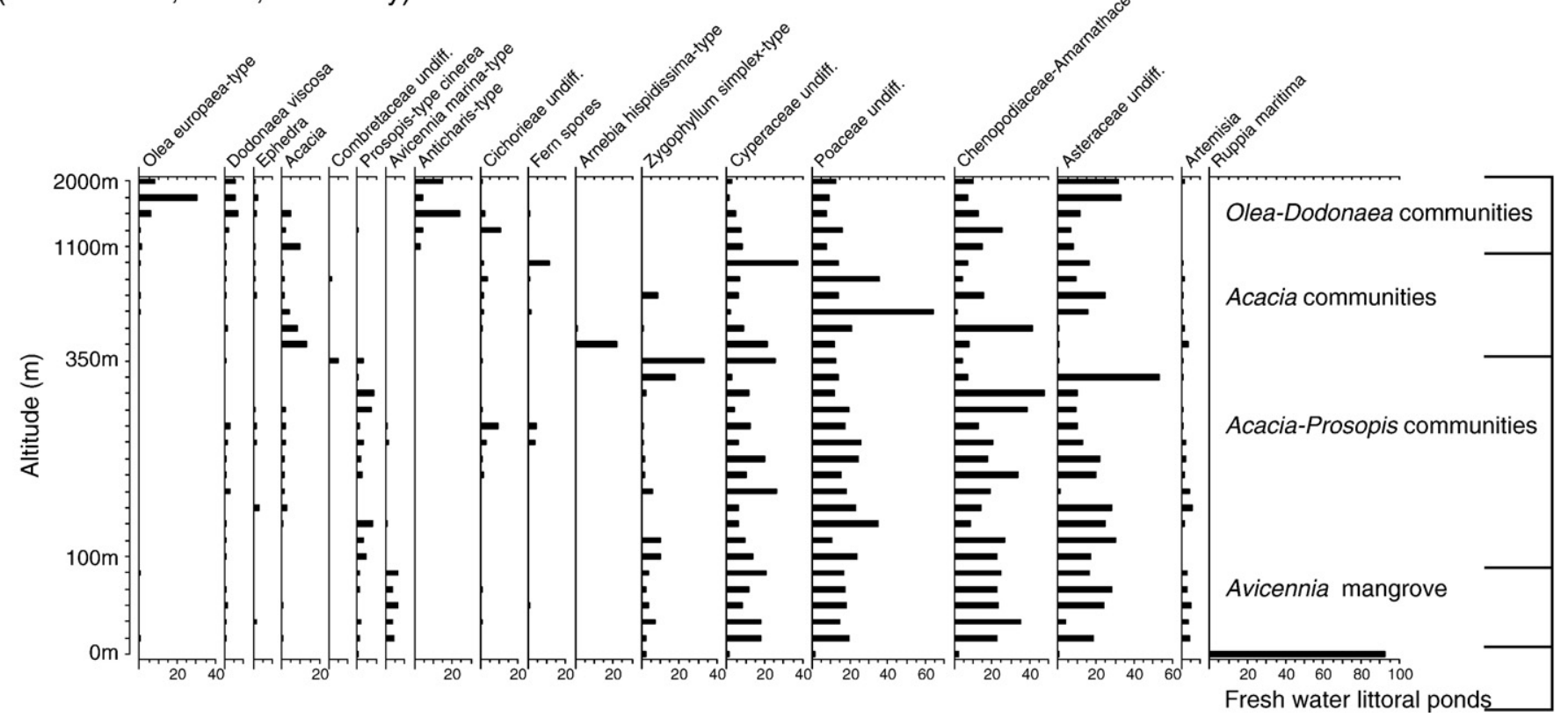

Fig. 2. Modern surface samples from the Arabian Peninsula. On the top, a latitudinal transect from Yemen to Iraq. On the bottom, an altitudinal transect from the sea shore to $2000 \mathrm{~m}$ alt in Oman. Percentages are calculated against the sum of all pollen grains and fern spores counted. Only the main taxa are presented. Data are available from the African Pollen Database (http://medias.obs-mip.fr/pad). 
Table 1

Location of modern pollen samples shown on Fig. 2.

\begin{tabular}{|c|c|c|c|}
\hline \multicolumn{4}{|l|}{ Modern pollen samples } \\
\hline Author sample name & $\begin{array}{l}\text { Latitude } \\
(\mathrm{N})\end{array}$ & $\begin{array}{l}\text { Longitude } \\
\text { (E) }\end{array}$ & Reference \\
\hline Kuwait-S. Iraq N & 29.67 & 47.72 & El-Moslimany (1983) \\
\hline Kuwait-S. Iraq $\mathrm{N}^{\circ} 8$ & 29.65 & 47.72 & El-Moslimany (1983) \\
\hline Kuwait-S. Iraq N9 & 29.60 & 47.80 & El-Moslimany (1983) \\
\hline Kuwait-S. Iraq N 12 & 29.57 & 48.13 & El-Moslimany (1983) \\
\hline Kuwait-S. Iraq N 10 & 29.43 & 47.73 & El-Moslimany (1983) \\
\hline Kuwait-S. Iraq N 14 & 29.13 & 48.13 & El-Moslimany (1983) \\
\hline Kuwait-S. Iraq N²0 & 28.38 & 48.70 & El-Moslimany (1983) \\
\hline Kuwait-S. Iraq N¹5 & 28.38 & 47.90 & El-Moslimany (1983) \\
\hline Kuwait-S. Iraq N 18 & 28.35 & 48.45 & El-Moslimany (1983) \\
\hline DHARAN-A & 26.05 & 49.83 & El-Moslimany (1983) \\
\hline DHARAN-B & 26.05 & 49.83 & El-Moslimany (1983) \\
\hline Site $36, \mathrm{M} 104$, a & 25.97 & 51,3 & Bonnefille and Riollet (1988) \\
\hline Khor F B, K 3S, a & 25.73 & 51.52 & Bonnefille and Riollet (1988) \\
\hline Khor M, 7, a & 25.73 & 51.52 & Bonnefille and Riollet (1988) \\
\hline RIHYAD-C & 24.42 & 46.80 & El-Moslimany (1983) \\
\hline JEDDAH-D & 22.92 & 39.08 & El-Moslimany (1983) \\
\hline RaK-01 & 22.87 & 50.00 & El-Moslimany (1983) \\
\hline RaK-02 & 19.93 & 49.00 & El-Moslimany (1983) \\
\hline RaK-03 & 19.83 & 47.63 & El-Moslimany (1983) \\
\hline RaK-04 & 19.00 & 47.53 & El-Moslimany (1983) \\
\hline Rak-08 & 18.83 & 45.75 & El-Moslimany (1983) \\
\hline RaK-05 & 18.47 & 47.13 & El-Moslimany (1983) \\
\hline RaK-07 & 18.35 & 46.50 & El-Moslimany (1983) \\
\hline RaK-06 & 18.30 & 46.97 & El-Moslimany (1983) \\
\hline Y96-40 & 15.87 & 46.68 & Lézine et al. (1998) \\
\hline Y96-03 & 15.75 & 46.32 & Lézine et al. (1998) \\
\hline Y96-08 & 15.70 & 46.37 & Lézine et al. (1998) \\
\hline Y96-138 & 15.48 & 45.40 & Lézine et al. (1998) \\
\hline Y96-140 & 15.42 & 45.17 & Lézine et al. (1998) \\
\hline Y96-139 & 15.40 & 45.30 & Lézine et al. (1998) \\
\hline 099-14b & 23.32 & 58.12 & This study \\
\hline 098-55 & 23.29 & 56.57 & This study \\
\hline 098-3b & 23.27 & 58.92 & Lézine et al. (2002) \\
\hline $098-6$ & 23.27 & 58.92 & Lézine et al. (2002) \\
\hline 099-12 & 23.24 & 57.20 & This study \\
\hline 099-12b & 23.24 & 57.20 & This study \\
\hline 099-13 & 23.24 & 57.19 & This study \\
\hline 098-53 & 23.20 & 57.14 & This study \\
\hline $098-54$ & 23.20 & 57.14 & This study \\
\hline 099-15 & 23.02 & 58.25 & This study \\
\hline 098-51 & 22.92 & 59.10 & This study \\
\hline 098-50 & 22.91 & 59.09 & This study \\
\hline $098-47$ & 22.69 & 59.34 & This study \\
\hline $098-41$ & 22.56 & 59.54 & Lézine et al. (2002) \\
\hline 098-42 & 22.56 & 59.53 & Lézine et al. (2002) \\
\hline $098-8$ & 22.55 & 59.52 & Lézine et al. (2002) \\
\hline 098-11 & 22.50 & 59.72 & Lézine et al. (2002) \\
\hline 099-19 & 22.50 & 58.95 & This study \\
\hline $098-17$ & 22.49 & 59.73 & Lézine et al. (2002) \\
\hline 098-18 & 22.49 & 59.73 & Lézine et al. (2002) \\
\hline 098-24 & 22.49 & 59.74 & Lézine et al. (2002) \\
\hline $098-25$ & 22.49 & 59.74 & Lézine et al. (2002) \\
\hline 098-26 & 22.49 & 59.74 & Lézine et al. (2002) \\
\hline $098-27$ & 22.49 & 59.74 & Lézine et al. (2002) \\
\hline 098-35 & 22.49 & 59.75 & Lézine et al. (2002) \\
\hline 098-36 & 22.49 & 59.75 & Lézine et al. (2002) \\
\hline $098-40$ & 22.45 & 59.69 & This study \\
\hline $098-2 b$ & 22.27 & 58.92 & Lézine et al. (2002) \\
\hline 098-10 & 22.24 & 59.77 & This study \\
\hline 098-9 & 22.04 & 59.66 & This study \\
\hline
\end{tabular}

investigations. Each sample was divided into two sub-samples: one sub-sample was crushed in a grinder and pressed into a holder for bulk mineral analyses. The other sub-sample was washed on a $63 \mu \mathrm{m}$ mesh. The $<63 \mu \mathrm{m}$ fraction was decalcified using a solution of $10 \%$ $\mathrm{HCl}$, rinsed with deionized water and deflocculated through repeated centrifugation. The clay fraction $(<2 \mu \mathrm{m})$ was separated by decantation and deposited onto a glass slide. X-ray diffraction analyses were conducted on natural clay slides, after ethylene-glycol salvation, and after heating at $490{ }^{\circ} \mathrm{C}$ during $2 \mathrm{~h}$. Percentage evaluations were based on peak intensities (counts at maximum height). For clay mineral quantification, the diagram obtained from the glycolated sample was used with weighing factors from Holtzapffel (1985). Grain size: because of high contents of terrigenous particles, grain-size analyses were conducted on samples from the al-Haid sequence using a Malvern Multisizer S lasersizer equipped with a 300RF lens. Results are given in percentages of sand, silt and clay, and sorting.

\subsubsection{Pollen and diatoms}

Samples for pollen analysis were processed using the standard HF method described by Faegri and Iversen (1975). After sieving in a $5 \mu \mathrm{m}$ mesh, the pollen residue was stained with basic fushin and mounted in glycerine. Counts averaged 450 grains per sample (with a maximum of 1134). Pollen identification were based on reference slide and photo collections of the African Pollen Database (http://medias.obs-mip.fr/apd) and the Museum national d'Histoire naturelle in Paris as well as on regional pollen atlases from Bonnefille and Riollet (1980), El-Ghazali (1991), and El-Ghazaly (1993). The pollen nomenclature, which follows the standard defined by the African Pollen Database (Vincens et al., 2007), is based on Wood (1997). Ecological and phytogeographical details come from Ghazanfar and Fisher (1998). For diatom analysis samples were processed using hydrogen peroxide (30\%) and hydrochloric acid (10\%). The residue was then dried up and mounted in Naphrax. A minimum of 400 specimens were counted per sample. Diatom identification was based on Germain (1981), Krammer and Lange-Bertalot (1986-1991), Simonsen (1987) and Ehrlich (1995). In addition, Gasse (1986), Sylvestre (1997) and Sylvestre et al. (2001) were used to characterize the ecological requirement of each diatom species.

\subsubsection{Age control}

Age control was established by liquid scintillation (Packard 2260 TR/ $\mathrm{XL}$ ) and by accelerator mass spectrometry (AMS) radiocarbon dating of gastropod shells and total organic matter. Analyses were conducted at LODYC (Paris) and at NSF Arizona and UMS-ARTEMIS AMS Facilities (Table 2). For continental samples, both gastropod shells and organic matter recorded similar $14 \mathrm{C}$ values. We therefore assume that the hard water effect was insignificant (Lézine et al., 2007). A reservoir correction has been applied (Saliège et al., 2005) to Holocene marine shells (from Suwayh and the littoral archaeological sites). This has been subtracted from the raw radiocarbon ages. Corrected radiocarbon ages were then calibrated to calendar ages using the Calib 5 program (Reimer et al., 2004). Both palaeoenvironmental and archaeological sets of data are presented in calibrated ages B.P. (with present equal to $1950 \mathrm{AD}$ ) (Table 2).

\subsection{Results}

With the exception of the Rada sequence in the highlands where the lacustrine sequence corresponds to $1 \mathrm{~m}$ thick almost pure diatomite, all paleolake/swamp extensions are constrained by authigenic and biogenic calcite rich deposits. Single lacustrine intervals have been recorded at Saada 1, Saada 3 and al-Haid, whereas a succession of four positive hydrologic events has been recorded at al-Hawa, which is detailed in Lezine et al. (2007) and summarized below.

\subsubsection{The lowland records}

4.2.1.1. Al-Hawa. Al-Hawa $\left(15^{\circ} 52 \mathrm{~N}, 46^{\circ} 53 \mathrm{E}, 710 \mathrm{~m}\right.$ asl) is a large flat basin located in the inland desert of Yemen, the Ramlat as-Sab'atayn, which is the southernmost extension of the Rub'al-Khali desert. The area is surrounded by dunes and fed by wadis, which drain the adjacent Yemen highlands and Hadramawt plateau. A $7.5 \mathrm{~m}$ thick section was recovered in 2002 mainly consisting in massive or finely laminated mudstone and siltstone interbeded with quartz rich sandy layers (Figs. 3 and 11). Fourteen 14C measurements on gastropod shells and organic matter yielded an age ranging from 11185 to 
Table 2

Radiocarbon measurements on late Quaternary lacustrine sediments from Southern Arabia studied by the authors.

\begin{tabular}{|c|c|c|c|c|c|c|c|}
\hline Site & Material & $\begin{array}{l}\text { Latitude } \\
(\mathrm{N})\end{array}$ & $\begin{array}{l}\text { Longitude } \\
\text { (E) }\end{array}$ & Laboratory number & $\begin{array}{l}{ }^{14} \text { C age } \\
\text { (yr B.P.) }\end{array}$ & $\begin{array}{l}\text { Calendar age B.P. } \\
(1 \mathrm{~s}) \text { (yr B.P.) }\end{array}$ & Reference \\
\hline \multicolumn{8}{|l|}{ Yemen lowlands } \\
\hline UnitA (al-Hawa-2 $02 \mathrm{~cm}$ ) & Melanoides tuberculata & 15.866667 & 46.883333 & Pa 1533 & $7215 \pm 80$ & $7961-8156$ & Lézine et al., 1998 \\
\hline UnitA (al-Hawa-2-25 cm) & Melanoides tuberculata & 15.866667 & 46.883333 & Pa-1531 & $7245 \pm 80$ & $7999-8162$ & Lézine et al., 1998 \\
\hline UnitA (al-Hawa-2 $72 \mathrm{~cm}$ ) & Melanoides tuberculata & 15.866667 & 46.883333 & Pa-1532 & $7580 \pm 80$ & $8316-8509$ & Lézine et al., 1998 \\
\hline al-Hawa-4 $85.5 \mathrm{~cm}$ & Melanoides tuberculata & 15.866667 & 46.883333 & Pa-1559 & $7465 \pm 80$ & $8201-8361$ & Lézine et al., 1998 \\
\hline al-Hawa-4 $85.6 \mathrm{~cm}$ & Calcite & 15.866667 & 46.883333 & Pa-1628 & $7800 \pm 60$ & $8464-8640$ & Lézine et al., 1998 \\
\hline Hawa-4 $95 \mathrm{~cm}$ & Melanoides tuberculata & 15.866667 & 46.883333 & Pa-1567 & $7780 \pm 80$ & $8458-8605$ & Lézine et al., 1998 \\
\hline UnitB (al-Hawa-2 $185 \mathrm{~cm}$ ) & Calcite & 15.866667 & 46.883333 & Pa-1631 & $8600 \pm 60$ & $9522-9651$ & Lézine et al., 1998 \\
\hline UnitB (al-Hawa-2 194 cm) & Organic matter & 15.866667 & 46.883333 & Pa-1580 & $8700 \pm 100$ & $9543-9866$ & Lézine et al., 1998 \\
\hline Shabwa $10 \mathrm{~cm}$ & Carbonate & 15.533333 & 46.916667 & $\mathrm{~Pa}-1764$ & $6330 \pm 80$ & $7166-7412$ & This study \\
\hline al-Hawa-1 $7.5 \mathrm{~cm}$ & Bellamya sp. & 15.866667 & 46.883333 & Pa-1996 & $6850 \pm 115$ & $7789-7587$ & Lézine et al., 2007 \\
\hline al-Hawa-1 57-62 cm & Organic matter & 15.866667 & 46.883333 & P24/AA32161 & $6920 \pm 60$ & $7921-7671$ & Lézine et al., 2007 \\
\hline al-Hawa-1 $285-291 \mathrm{~cm}$ & Organic matter & 15.866667 & 46.883333 & P26/AA32163 & $7372 \pm 81$ & $8325-8041$ & Lézine et al., 2007 \\
\hline al-Hawa-1 $322-331 \mathrm{~cm}$ & Organic matter & 15.866667 & 46.883333 & P28/AA32165 & $7317+80$ & $8183-8018$ & Lézine et al., 2007 \\
\hline al-Hawa-1 $337 \mathrm{~cm}$ & Melanoides tuberculata & 15.866667 & 46.883333 & P29/AA32166 & $7700+82$ & $8588-8395$ & Lézine et al., 2007 \\
\hline al-Hawa-1 $428.7 \mathrm{~cm}$ & Bellamya sp. & 15.866667 & 46.883333 & P328/AA50810 & $7866 \pm 74$ & $8929-8561$ & Lézine et al., 2007 \\
\hline al-Hawa-1 $634.9 \mathrm{~cm}$ & Shell fragment & 15.866667 & 46.883333 & P370/SacA103351 & $7851 \pm 49$ & $8694-8590$ & Lézine et al., 2007 \\
\hline al-Hawa-1 $641.7 \mathrm{~cm}$ & Shell fragment & 15.866667 & 46.883333 & $\mathrm{~Pa}-2146$ & $8105 \pm 60$ & $9226-9005$ & Lézine et al., 2007 \\
\hline al-Hawa-1 $649.7 \mathrm{~cm}$ & Melanoides tuberculata & 15.866667 & 46.883333 & Pa-2091 & $8150 \pm 60$ & $9248-9013$ & Lézine et al., 2007 \\
\hline al-Hawa-1 $682.7 \mathrm{~cm}$ & Melanoides tuberculata & 15.866667 & 46.883333 & P368/SacA103347 & $8809 \pm 52$ & 10180-9915 & Lézine et al., 2007 \\
\hline al-Hawa-1 $688.7 \mathrm{~cm}$ & Melanoides tuberculata & 15.866667 & 46.883333 & P369/SacA103350 & $8834+54$ & $10148-9776$ & Lézine et al., 2007 \\
\hline al-Hawa-1 $705.2 \mathrm{~cm}$ & Melanoides tuberculata & 15.866667 & 46.883333 & P364/SacA103349 & $9280+55$ & $10558-10291$ & Lézine et al., 2007 \\
\hline al-Hawa-1 $716.9 \mathrm{~cm}$ & Melanoides tuberculata & 15.866667 & 46.883333 & P365/SacA103344 & $9327 \pm 54$ & $10637-10428$ & Lézine et al., 2007 \\
\hline al-Hawa-1 $723.1 \mathrm{~cm}$ & Bellamya sp. & 15.866667 & 46.883333 & P363/SacA103348 & $9340 \pm 53$ & $10667-10430$ & Lézine et al., 2007 \\
\hline al-Hawa-1 $726.7 \mathrm{~cm}$ & Melanoides tuberculata & 15.866667 & 46.883333 & P366/SacA103345 & $9656 \pm 54$ & 11169-10813 & Lézine et al., 2007 \\
\hline \multicolumn{8}{|l|}{ Yemen highlands } \\
\hline Rada-0 & Fresh-water shells & 14.43465 & 44.821717 & Pa-1738 & $4770 \pm 80$ & $5332-5590$ & This study \\
\hline Rada-0 & Fresh-water shells & 14.43465 & 44.821717 & SacA2940 & $5150 \pm 60$ & $5760-5988$ & This study \\
\hline Rada- $65 / 72 \mathrm{~cm}$ & Fresh-water shells & 14.43465 & 44.821717 & SacA2939 & $5290 \pm 50$ & $5993-6178$ & This study \\
\hline Saada $15 \mathrm{~cm}$ & Carbonate & 17.009328 & 43.750997 & Pa-1736 & $4365 \pm 100$ & $5263-4838$ & This study \\
\hline Saada $330 \mathrm{~cm}$ & Carbonate & 17.007944 & 43.755186 & Pa-1737 & $6390 \pm 100$ & $7427-7185$ & This study \\
\hline \multicolumn{8}{|l|}{ Oman lowlands } \\
\hline al-Haid & Shell fragment & 21.28705 & 59.0807 & $\mathrm{~Pa}-1820$ & $6570 \pm 80$ & $7564-7425$ & This study \\
\hline Suwayh-1 $135 \mathrm{~cm}$ & Amiantis umbonella & 22.08815 & 59.667217 & $\mathrm{~Pa}-1767$ & $4570 \pm 60$ & $4530-4390$ & Lézine et al., 2002 \\
\hline Suwayh-1 $169.5 \mathrm{~cm}$ & Amiantis umbonella & 22.08815 & 59.667217 & Pa-1765 & $5045 \pm 35$ & $5211-4992$ & Lézine et al., 2002 \\
\hline Suwayh-1 $182-187 \mathrm{~cm}$ & Saccostrea cucullata & 22.08815 & 59.667217 & Pa-1794 & $5760 \pm 100$ & $5990-5769$ & Lézine et al., 2002 \\
\hline Suwayh-2 $200-230 \mathrm{~cm}$ & Shell fragment & 22.08815 & 59.667217 & Pa-2029 & $5605 \pm 60$ & $5842-5646$ & Lézine et al., 2002 \\
\hline
\end{tabular}

$7586 \mathrm{cal}$ yr B.P. At the South easternmost part of the basin, near the city of Shabwa $\left(15^{\circ} 32 \mathrm{~N}, 46^{\circ} 55 \mathrm{E}\right)$, a $20 \mathrm{~cm}$ thick layer of pure calcite has been dated from 7413 to $7167 \mathrm{cal}$ yr B.P., showing that the lacustrine period did not end at 7500 cal yr B.P. and still lasted for few centuries.

4.2.1.1.1. Bulk mineralogy. The mineralogy of the bulk sediment is largely dominated by quartz (5\% to $90 \%$ ) and calcite (5\% to $90 \%$ ). Quartz is associated with smaller amounts of feldspars (traces to $50 \%$ ). These minerals are typically terrigenous, eroded from substrates by physical weathering and transported by winds. They are major components of the Rub' al-Khali sand dunes (El-Sayed, 1999). High contents of quartz, feldspars and related minerals in the sediments of al-Hawa may indicate intervals of enhanced aridity and eolian activity. Wind activity peaked at 350 (8500 cal yr B.P.) and $220 \mathrm{~cm}$ ( $7980 \mathrm{cal} \mathrm{yr} \mathrm{B.P.),} \mathrm{and} \mathrm{from} 140$ to $70 \mathrm{~cm}$ (7900-7800 cal yr B.P.).

Calcite mostly consists of silt-sized and clay-sized particles of authigenic origin (Lézine et al., 1998, 2007). Similar particles of authigenic calcite have been described in modern lacustrine environments of temperate and tropical latitudes (Stabel, 1986; Talbot and Allen, 1996). In the Holocene environment of al-Hawa, dissolved calcium and bicarbonates from the drainage basin have probably been transported by run-off to the lake. Significant proportion of similar carbonates has been found in the Rub' al-Khali (El-Sayed, 1999), in association with quartz and feldspars. It is therefore likely that in the al-Hawa area some calcite could be reworked, especially when associated with high amounts of typically terrigenous minerals. However, it is assumed that high proportions of calcite may represent genuine intervals of lacustrine environment, as attested by the association of shell fragments and authigenic calcite. The highest contents of biogenic and authigenic carbonates record major lacustrine developments from 730 to $720 \mathrm{~cm}$ (11 800-10500 cal yr B.P.), 690 to $650 \mathrm{~cm}$ (10 200-9100 cal yr B.P.), 340 to $310 \mathrm{~cm}(8080-8420 \mathrm{cal} \mathrm{yr}$ B.P.) and 60 to $10 \mathrm{~cm}(7800-7500 \mathrm{cal}$ yr B.P.). Needle-like, silt-sized particles of aragonite are present in significant amounts from $690 \mathrm{~cm}$ to $720 \mathrm{~cm}$. Aragonite is most probably authigenic, and may have formed as concentration increased in the lake, probably due to intense evaporation (Stabel, 1986; Talbot and Allen, 1996).

Clay minerals (0 to 30\%) are generally a relatively minor component of the sediment, with the exception of the interval extending from 650 to $500 \mathrm{~cm}$ (9100-8800 cal yr B.P.). They are derived from soils and sediments, eroded and transported by running waters and winds. The scarcity of clay minerals in many types of sediment from the al-Hawa section suggests that chemical weathering remained weak most of the time.

4.2.1.1.2. Clay mineralogy. The clay mineral assemblage includes chlorite ( 0 to $10 \%$ ), illite ( 0 to $55 \%$ ), random mixed-layered clays ( 0 to $15 \%$ ), smectite ( 0 to $85 \%$ ), kaolinite ( 0 to $20 \%$ ) and palygorskite ( 0 to $75 \%$ ). A similar assemblage has been evidenced from previous studies in the al-Hawa area, which suggested that the minerals are principally terrigenous, derived from eolian activity. However, it is possible that some kaolinite and smectite are formed in the adjacent drainage basin at times of more humid conditions (Lézine et al., 1998, 2007).

Bulk and clay mineralogy in the lowermost part of the section (from 740 to $670 \mathrm{~cm}$ ) reflect a perennial but fluctuating lacustrine 


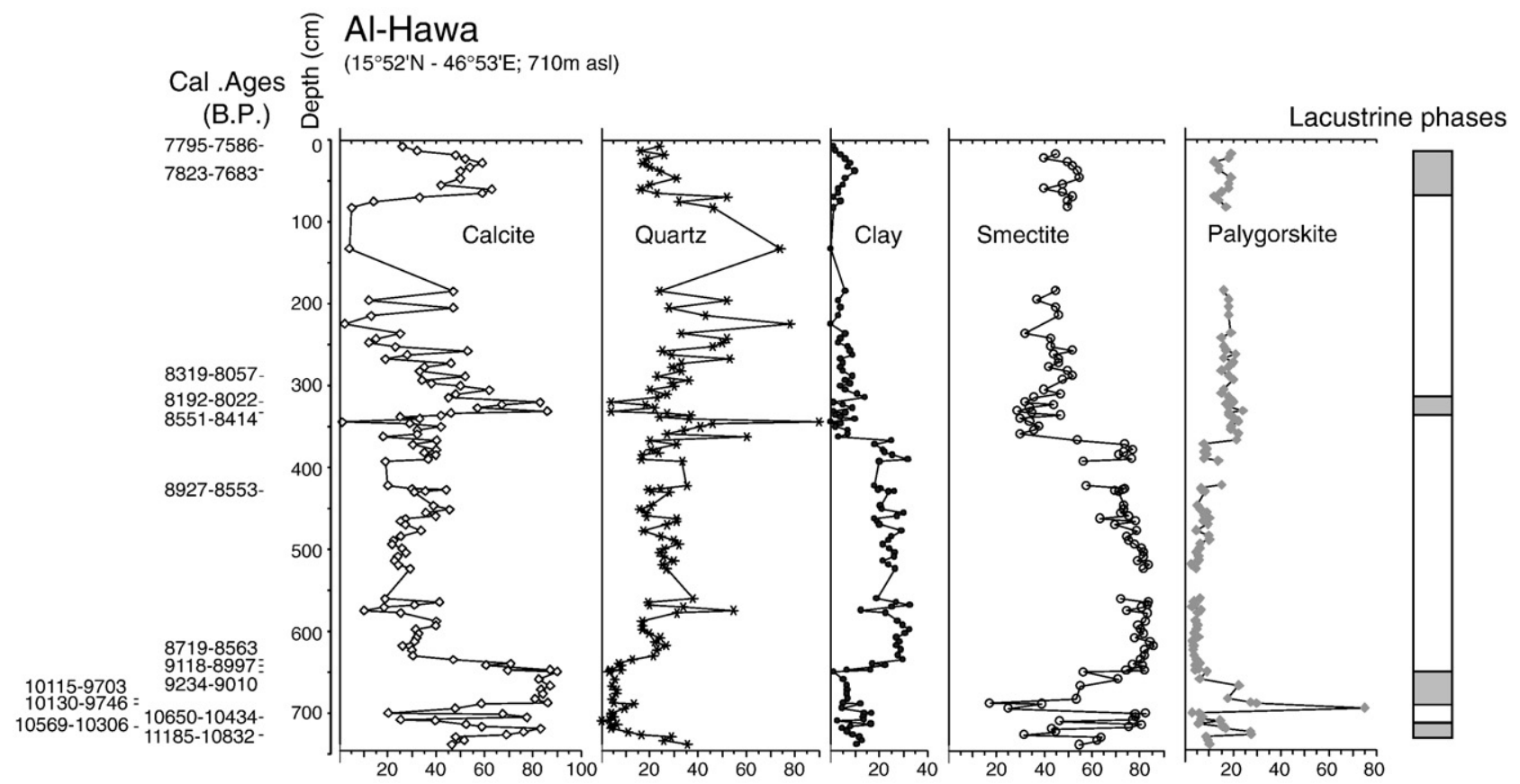

Fig. 3. Sedimentology and clay mineralogy for al-Hawa Palolake (Yemen), synthetic diagrams. Only the main characteristics of the environmental evolution are presented. Data are presented versus depth (in $\mathrm{cm}$ ) with indication of calendar ages (B.P.) on the left. The phases of lacustrine extensions deduced from variations in calcite composition of the bulk sediment are presented on the right.

environment, with dryer intervals resulting in concentration of lake waters, desiccation of the flood-plain, and increased mineral authigenesis (Lézine et al., 2007).

The clay mineral assemblage of the lower part of the section (from $740 \mathrm{~cm}$ to $460 \mathrm{~cm}$ ) is largely dominated by smectite. Significantly higher proportions of this mineral in the al-Hawa section compared to dust fall-out and other locations in Arabia and the Arabian Sea suggest a local origin for at least part of the smectite. Smectite is a typical product of chemical weathering in semi-arid areas, which formed through pedogenic processes and/or authigenesis in poorly drained downstream areas of the drainage basin. This implies a seasonality of precipitation: chemical elements carried to downstream areas by runoff concentrate in the flood-plains during the dry season and favour smectite formation (Chamley, 1989; Weaver, 1989).

The clay mineral assemblage of the upper part of the section (top to $360 \mathrm{~cm}$ ) is very similar to those observed in other parts of the al-Hawa area and in the Arabian Sea (Sirocko and Lange, 2001; Fagel et al., 1992) where they mostly result from eolian activity. Moreover, it is also similar to those observed in dust fallouts of southern Mesopotamia (Aqrawi,
2001). Therefore, this clay assemblage is considered as mainly derived from eolian activity with little contribution from run-off in adjacent drainage basin, even during intervals of lake expansion.

4.2.1.2. Al-Haid. The $2.5 \mathrm{~m}$ thick section of al-Haid is situated the Indian Ocean shore at $21^{\circ} 17^{\prime} 223 \mathrm{~N}$ and $59^{\circ} 04^{\prime} 842 \mathrm{E}$ (Fig. 4). It is composed $1.5 \mathrm{~m}$ thick terrigenous siltstone to sandstone layers containing root-prints corresponding to a swamp deposit overlying $1 \mathrm{~m}$ thick accumulation of beach sands. Fresh-water gastropod shells (Melanoides tuberculata) taken at $90 \mathrm{~cm}$ depth from the top of the section yielded an age of 7564-7425 cal yr B.P (table). In spite of large dating uncertainties, additional IRSL dating by Preusser et al. (2005) on the same section suggest that the swamp developed at the same time as the littoral dune or immediately after. An IRSL age of $3600 \pm 400$ cal yr B.P. measured at nearly the same level as the gastropod rich one does not fit with our $14 \mathrm{C}$ date and pose the problem of possible contaminations by more recent sediments. The description below is focussed on the upper, swampy, layers of the section.

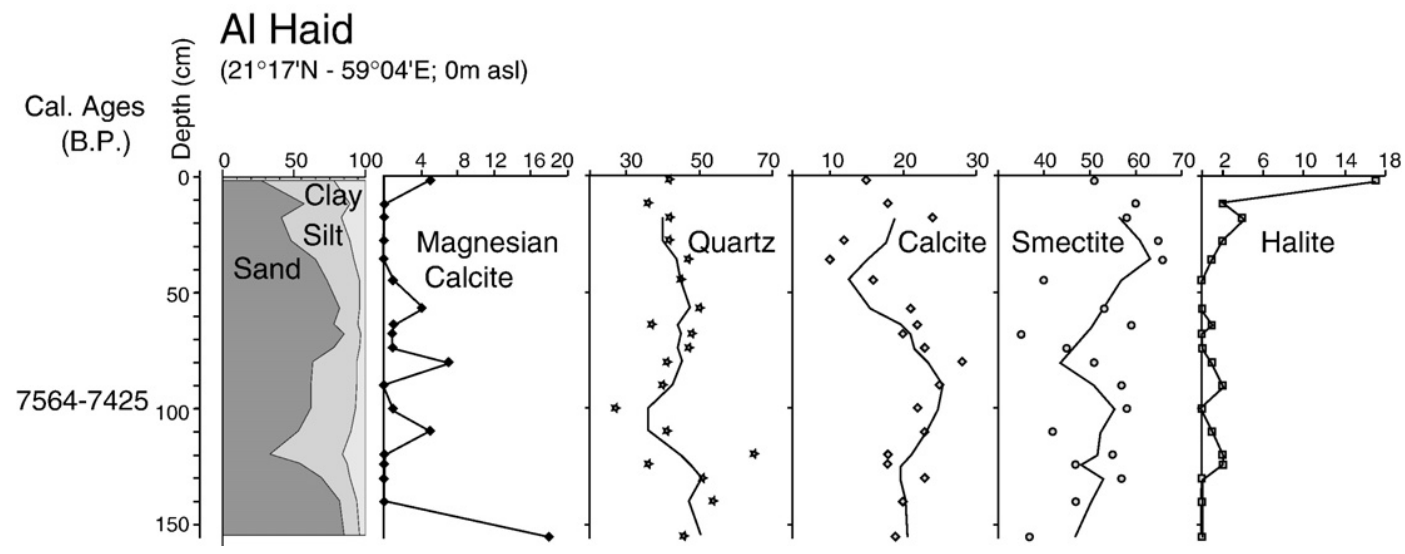

Fig. 4. Sedimentology and clay mineralogy for al-Haid swamp (Oman), synthetic diagrams. 
4.2.1.2.1. Bulk mineralogy. The mineralogy of the bulk sediment is dominated by terrigenous minerals, mainly quartz (25\% to $65 \%$ ) which is associated with smaller proportions of feldspars (10\% to $40 \%$ ). The highest contents of quartz below $110 \mathrm{~cm}$ indicate maximum physical weathering in relation to regional aridity. Calcite (10\% to $30 \%$ ) consists of silt-sized and clay-sized particles of authigenic origin. It is assumed that the highest proportions of calcite may represent genuine intervals of lacustrine development as attested by the local presence of shells, whereas the lowest contents of calcite (below $110 \mathrm{~cm}$ and above $45 \mathrm{~cm}$ ) coincide with intervals of maximum aridity and/or eolian activity. Part of the calcite is magnesian in nature (up to $20 \%$ ) in some intervals $(155 \mathrm{~cm}, 110 \mathrm{~cm}, 80 \mathrm{~cm}, 57 \mathrm{~cm}$ and top of the section) which represents increased evaporation and concentration of the lacustrine environment. The sediment also contains a proportion of halite ( $0 \%$ to $15 \%$ ) and dolomite ( $0 \%$ to $5 \%$ ) which reflects a probable influence of sea-water to the al-Haid sedimentary environment. This influence becomes significant in the topmost part of the section (above $10 \mathrm{~cm}$ ). Clay minerals represent only a very minor part of the bulk sediment (trace amounts). They are derived from soils and sediments, eroded and transported by running waters and winds. The scarcity of clay minerals in the al-Haid section suggests that chemical weathering remained weak, as a probable consequence of strong aridity.

4.2.1.2.2. Clay mineralogy. The clay mineral assemblage includes chlorite (5\% to $10 \%$ ), illite (5\% to $10 \%$ ), random mixed-layered clays ( $0 \%$ to $15 \%$ ), smectite (35\% to $65 \%$ ), kaolinite (0\% to $5 \%$ ) and palygorskite (20\% to $40 \%$ ). Such an assemblage is considered as mainly derived from eolian activity with little contribution from run-off in adjacent drainage basin, even during the swamp events. However, the contents of smectite (and ransom mixed-layers) increase in the upper part of the section above $45 \mathrm{~cm}$, while abundances of all other clay minerals decrease. This may reflect a dilution of the dominant eolian assemblage by an increased smectite of local origin. Increased abundances of smectite coincide with an interval of encroaching aridity which follows the maximum swamp development in the al-Haid area.

\subsubsection{The upland records}

4.2.2.1. Rada. The paleolake of Rada $\left(14^{\circ} 26^{\prime} 079 \mathrm{~N}, 44^{\circ} 49^{\prime} 303 \mathrm{E}, 2000 \mathrm{~m}\right.$ asl) occupies a large endoreic depression located North of the modern city, near the village of al-Hijfah. The depression is bounded by Miocene to Quaternary basaltic plateaus and a Quaternary volcano to the West, and by Proterozoic acid intrusive and metamorphosed rocks to the East. A $1 \mathrm{~m}$ thick diatomite section is overlain by about $2 \mathrm{~m}$ thick beige silt layer corresponding to river flooding events (Fig 5). Two gastropod rich intervals situated at $22.5 \mathrm{~cm}$ and at the top of the sequence yielded an age of 6030 and $5870 \mathrm{cal}$ yr B.P.

4.2.2.1.1. Bulk mineralogy. The mineralogy of the bulk sediment is dominated by opal CT ( $55 \%$ to $90 \%$ ), which results from the diagenetic alteration of biogenic amorphous silica. The highest concentrations between $72.5 \mathrm{~cm}$ and $44.5 \mathrm{~cm}$ probably correspond to maximum productivity of the lacustrine environment. The dissolved silica necessary for the full development of biosiliceous organisms is most probably derived from the leaching of basaltic outcrops which dominate in the drainage basin. Authigenic calcite is relatively low (below $20 \%$ ) because of the scarcity of carbonate rocks in the drainage basin, with the highest abundances being recorded in the lower and upper parts of the section. Terrigenous minerals mostly include quartz (5\% to $20 \%$ ) and feldspars (traces to $5 \%$ ), which contribute from both regional physical weathering and wind activity. Slightly higher abundances in the lower and upper parts of the section most probably result from decreased dilution by opal (lower productivity) and/or increased contribution from the drainage basin. Low abundances of clay minerals (traces to 5\%) suggest however that chemical weathering remained weak in the drainage basin of the Rada lacustrine environment.
4.2.2.1.2. Clay mineralogy. The clay mineral assemblage includes chlorite ( $0 \%$ to $10 \%$ ), illite (5\% to $10 \%)$, random mixed-layered clays ( $0 \%$ to $15 \%$ ), smectite ( $30 \%$ to $55 \%$ ), kaolinite (5\% to $20 \%$ ) and palygorskite (15\% to $35 \%$ ). The clay mineral assemblage mostly reflects the eolian contribution to the Rada sediment. However, slightly higher abundances of kaolinite and random mixed-layers in the upper part of the section may result from increased contribution from the drainage basin because of intensified run-off. Correlative decrease of the abundance of smectite may reflect decreased importance of the contribution from flood-plain areas to the sediment as the lacustrine environment expanded.

4.2.2.1.3. Diatom assemblage. Sixty-seven species from 27 genera have been identified. Except for rare planktonic species (Cyclotella meneghiniana, C. michiganiana), the diatom assemblage is dominated by periphytic species (e.g., Pseudostaurosira brevistrata) suggesting that the water body remained relatively shallow during the whole lacustrine period. Three main phases have been identified from diatom assemblages: from the base to $70 \mathrm{~cm}$ the progressive filling of the depression is recorded by the occurrence of Rhopalodia operculata, Denticula elegans, and Nitschia microsepala indicative of shallow, oligosaline to mesosaline, waters. The occurrence in noticeable percentages of Amphora coffeaeformis at the bottom of the sequence (from the base to $78 \mathrm{~cm}$ ) suggests that the onset of the lacustrine phase was characterized by more saline, evaporitic conditions. The increase of Pseudostaurosira brevistriata, above $70 \mathrm{~cm}$, suggests that the saline lowstand ended with a transgression recorded by the development of the tychoplanktonic fresh-water species Synedra ulna. Then, toward the top of the sequence, the occurrence of Mastogloia elliptica and Achnanthes minutissima suggests the setting of an oligosaline, shallow, water body at the end of the lacustrine period. The peak of Fragillaria capucina capucina, is coeval with that of kaolinite within the clay fraction at $33.5 \mathrm{~cm}$ and suggests a short phase of fresh-water input into the lake. The abrupt transition between the diatomite section and the overlying silt, flood deposit, at the top to the Rada section suggests that the lacustrine record was partly eroded.

4.2.2.2. Saada. The Saada paleolake $\left(17^{\circ} 00^{\prime} 30 \mathrm{~N}-43^{\circ} 45^{\prime} 10 \mathrm{E}, 1800 \mathrm{~m}\right.$ asl) lies in a large, flat, endoreic depression located at the immediate vicinity of the At Tawilah village few kilometres north of Saada. The depression is fed by wadis which drain the surrounding plateaus mostly consisting of Jurassic limestones and calcareous sandstones to the South, and of Proterozoic metamorphosed rocks to the North. Two sections $1 \mathrm{~m}$ and $85 \mathrm{~cm}$ thick respectively were sampled: Saada 1, at the western edge of the depression and Saada 3, about $300 \mathrm{~m}$ toward the centre of the depression (Fig. 6). In both sites, the succession starts with a dark, paleosoil-like, unconsolidated level passing upward into a white calcareous layer containing abundant fresh-water gastropod shells. The dating of these make it possible to affirm that the two sections correspond to two distinct lake phases about 2000 years apart, around 5000 and 7300 cal B.P., respectively.

4.2.2.2.1. Bulk mineralogy. The mineralogy of the bulk sediment in the lower part of both sections is dominated by terrigenous minerals which mostly include quartz (35\%-55\% at Saada 3 and $10 \%-40 \%$ at Saada 1 ), feldspars (15\%-25\% at both sites) and clay minerals (10\%-15\% at Saada 3 and around $10 \%$ at Saada 1 ). Terrigenous minerals are associated to lower amounts of authigenic calcite (5\%-15\% at Saada 3 and $20 \%-40 \%$ at Saada 1). A major event, similar in nature and magnitude in both sections, consists in a rapid increase of authigenic calcite and correlative decrease of terrigenous minerals. Authigenic calcite increases to abundances of 45\%-95\% at Saada 3, and 65\%-95\% at Saada 1. This major mineralogical change reflects the development of a lacustrine environment, dissolved carbonates being supplied by run-off. The presence of higher contents of terrigenous minerals at Saada 3 than at Saada 1 suggests that regional erosion was probably more pronounced around $7300 \mathrm{cal}$ yr B.P. than around $5000 \mathrm{cal} \mathrm{yr} \mathrm{B.P.}$ 


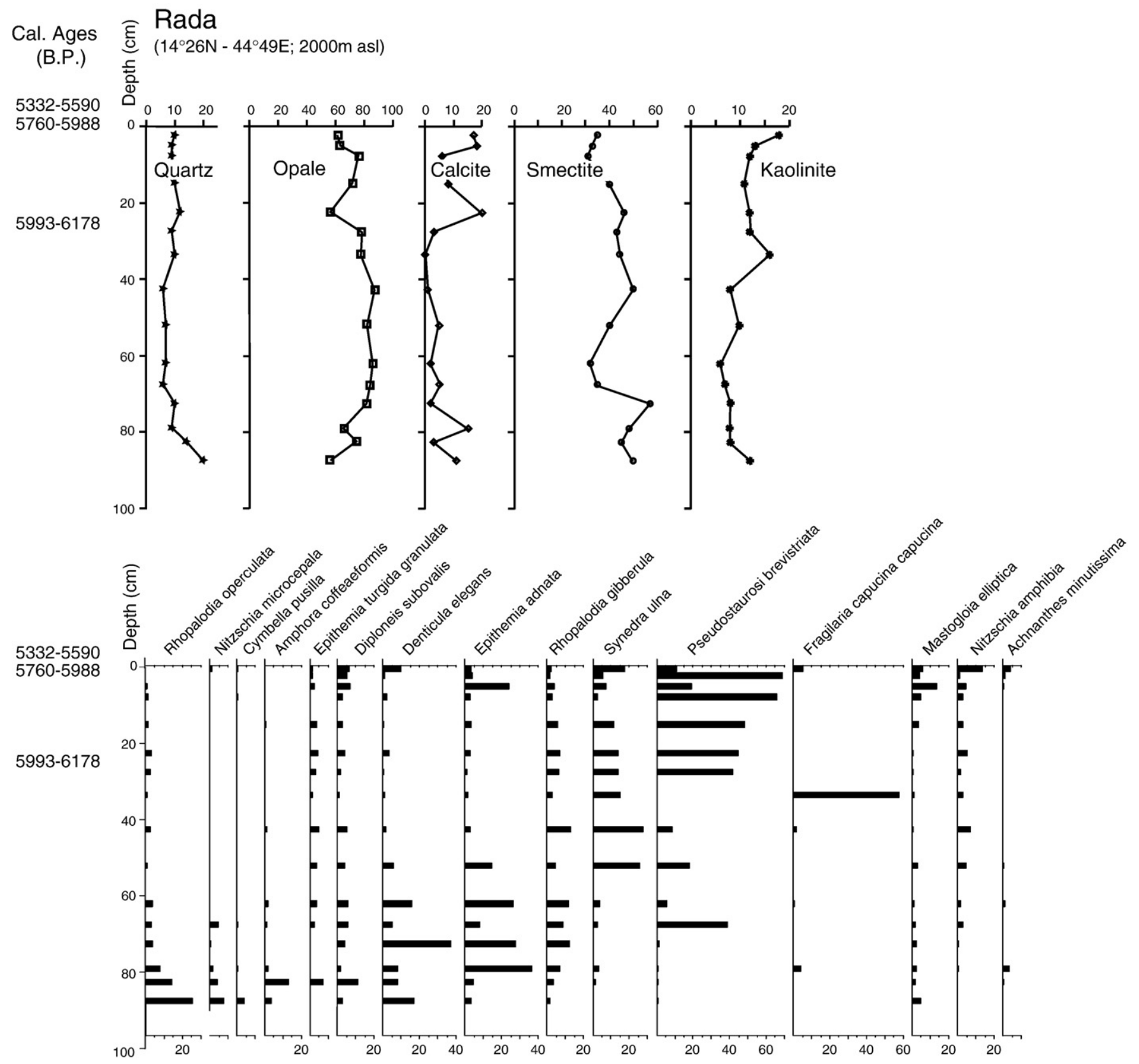

Fig. 5. Sedimentology, clay mineralogy and main diatom species for Rada diatomite (Yemen).

4.2.2.2.2. Clay mineralogy. The clay mineral assemblages include chlorite (5\%-10\% at Saada 3 and around $10 \%$ at Saada 1$)$, illite (5\%-10\% at Saada 3 and around $15 \%$ at Saada 1$)$, random mixed-layers ( $0 \%-5 \%$ at Saaada 3 and $0 \%-15 \%$ at Saada 1 ), smectite (45\%-75\% at Saada 3 and $30 \%-40 \%$ at Saada 1$)$, kaolinite (5\%-15\% at both sites) and palygorskite (10\%-25\% at Saada 3 and around $25 \%$ at Saada 1$)$. The dominance of smectite in the lower part of Saada 3 section (together with relatively abundant clay minerals in the bulk sediment) suggests significant chemical weathering around $7300 \mathrm{cal}$ yr B.P. Smectite formation was probably made possible by the presence of flood-plain areas near the lake, and a seasonality of precipitation. Its decrease at $30-35 \mathrm{~cm}$ as the abundance of authigenic calcite rises, suggests a reduction of flood-plain areas as the lacustrine environment expanded. Clay mineral assemblages in the upper part of Saada 3 section and at Saada 1 reflect a major contribution of eolian activity to the clay assemblages, and the paucity of chemical weathering in the drainage basin.

\section{The lowland vegetation environment}

Pollen data from the Southern Arabian lowlands are rare, as only six sites have provided interpretable pollen spectra. Due to conditions of extreme aridity, pollen grains are usually poorly preserved and some sites have provided a very limited number of pollen spectra such as in the Rub' al-Khali (El-Moslimany, 1983). In this context, the alHawa pollen diagram appears as an exceptional, continuous, early to mid-Holocene record of vegetation changes. Additional data from two well distinct climate regions: the Rub' al-Khali to the North and the Arabian Gulf (Bonnefille and Riollet, 1988; Garcia Anton and Sainz Ollero, 1999; Parker et al., 2004) to the North-East, and the Indian 

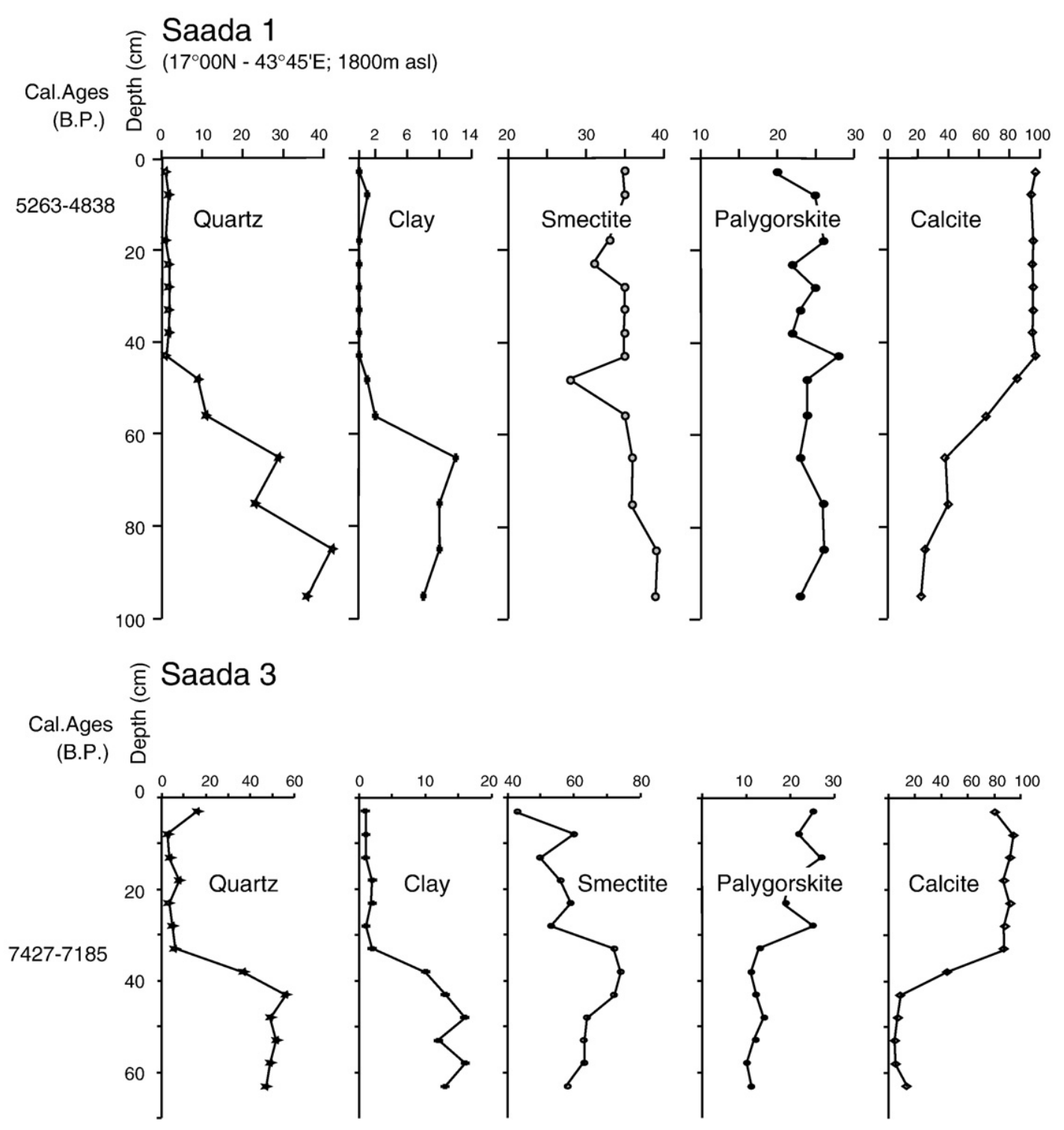

Fig. 6. Sedimentology and clay mineralogy for Saada 1 and Saada 3 (Yemen) showing the evolution of the sedimentary environment for two well distinguished lacustrine phases of the mid- to late Holocene.

Ocean (Lézine et al., 2002) to the East, complete our record of Holocene environmental change in the Arabian lowlands.

\subsection{Al-Hawa}

Sixty height samples were analyzed for pollen analysis (Fig. 7). They yielded an abundant microflora composed of 91 pollen taxa. The assemblage is mainly composed of lowland vegetation pollen types including Amaranthaceae-Chenopodiaceae, Cyperaceae, Poaceae, Typha. These taxa account for high pollen percentages, reaching up to $80,75,80$, 56, and 77\%, respectively. Tree pollen, mainly Acacia and Commiphora do not reach values more than $2 \%$, whereas the other elements of the lowland vegetation (Tamarix, Ziziphus-type, and Salvadora persica-type) occur only in trace amounts. Two main periods can be considered: from the base of the sequence (11 $850 \mathrm{cal} \mathrm{yr} \mathrm{B.P.)} \mathrm{to} \mathrm{about} 250 \mathrm{~cm}$ ( $8000 \mathrm{cal} \mathrm{yr}$ B.P.), the filling of the lake occurred very rapidly, in less than 500 years, as recorded by the replacement of Amaranthaceae/Chenopodiaceae, (which is indicative of saline, evaporitic, conditions), by Cyperacae, Poaceae, and Typha, then by Pteridophyta. These taxa dominate during the time interval from $10500 \mathrm{cal} \mathrm{yr} \mathrm{B.P.} \mathrm{to} \mathrm{the} \mathrm{end} \mathrm{of} \mathrm{the} \mathrm{period,} \mathrm{indicating} \mathrm{that} \mathrm{the}$ waters of the al-Hawa paleolake became fresh (e.g., Typha and Pteris vitata) and that the surrounding environment was characterized by an important herbaceous cover (Cyperaceae and Poaceae). The tropical trees of Somalia-Masaï origin cited above are also present during the whole period. However, their low values indicate that they did not represent dense plant communities. From 8000 to the top of the pollen sequence (7700 cal yr B.P.), the disappearance of tree pollen types and the increase of Tribulus and Zygophyllum simplex indicate that dry conditions prevailed. In addition to regional environmental variations, the pollen diagram record variations in reed-swamp and lake-shore herbaceous populations (Typha and Ferns) which are interpreted as reflecting lake level changes. High percentages of these pollen types indicate the development of hygrophilous herbaceous populations around the lake during phases of low level in accordance with the sedimentological and mineralogical records.

\subsection{Rub' al-Khali}

The Rub' al-Khali lacustrine deposits were analyzed by El-Moslimany (1983). Only a few samples contained abundant pollen. Three samples from the Mundafan paleolake $\left(18^{\circ} 32 \mathrm{~N}, 45^{\circ} 23 \mathrm{E}\right)$, are reported here, since their age is well constrained (about $8075 \mathrm{cal} \mathrm{yr} \mathrm{B.P.)} \mathrm{and} \mathrm{their}$ 


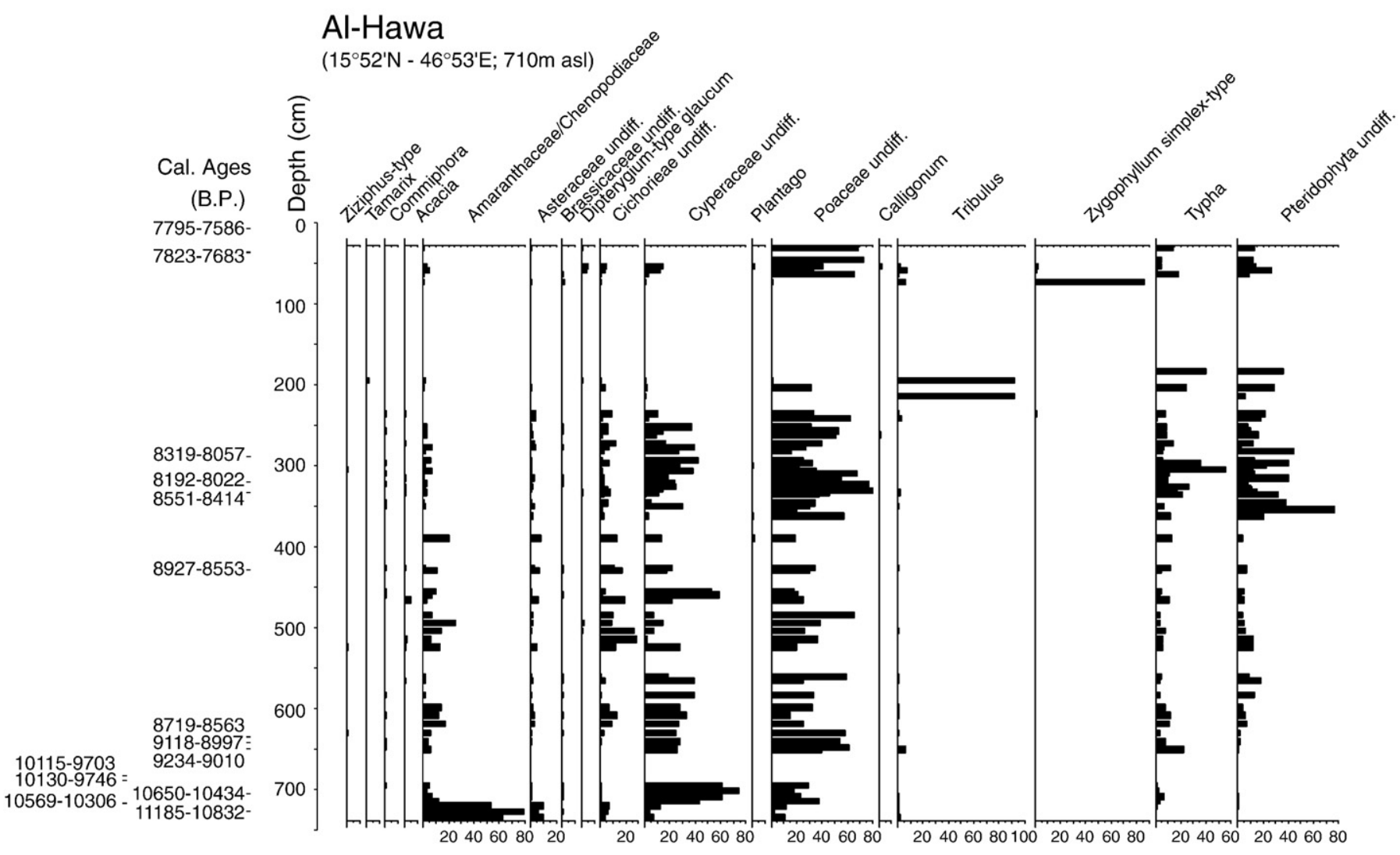

Fig. 7. Synthetic pollen diagram for al-Hawa (Yémen) showing, according to depth the percentages of the main lowland pollen types.

pollen content significant, with a pollen sum ranging from 82 to 274 (Fig. 8). The Mundafan paleolake was fed by wadis draining the back slopes of the high Mountains which border the Arabian Peninsula to the West. The pollen content of Holocene samples with Amaranthaceae/ Chenopodiaceae, Poaceae and Plantago pollen types differs drastically from the modern ones in the Mundafan area, characterized by Cyperaceae and Calligonum. This, together with the absence of Dipterygium glaucum and the presence of Pinus in the Holocene samples suggests stronger affinities with modern samples located north of $23^{\circ} \mathrm{N}$ than with those from the central Rub' al-Khali. Significant amounts of Poaceae indicates that sand dunes were stabilized and that climate conditions were more humid than today. However, tree pollen grains are very rare, recording an open, desert type, landscape.
5.3. The North-Eastern sites of the Rub' al-Khali desert: At Awafi and Wadi Yudayah

At the North-Eastern edge of the Rub' al-Khali desert, the lacustrine site of At Awafi $\left(25^{\circ} 42^{\prime} 57 \mathrm{~N}, 57^{\circ} 55^{\prime} 57 \mathrm{E}, 6 \mathrm{~m}\right.$ asl $)$ is located near the coast on the western slope of the Northern Omani Mountains (Parker et al., 2004). The lacustrine sequence yielded pollen and phytolith data, which allow characterization of the vegetation landscape between 8125 and $5298 \mathrm{cal}$ yr B.P. The pollen diagram (Fig. 9) records the development of trees, mainly Acacia and Prosopis during the period of maximum lake extension (8100-5900 cal yr B.P.), with abundant Gramineae (Pooideae). Such pollen spectra are remarkably similar to those from the present day low altitude Acacia/Prosopis woodlands of

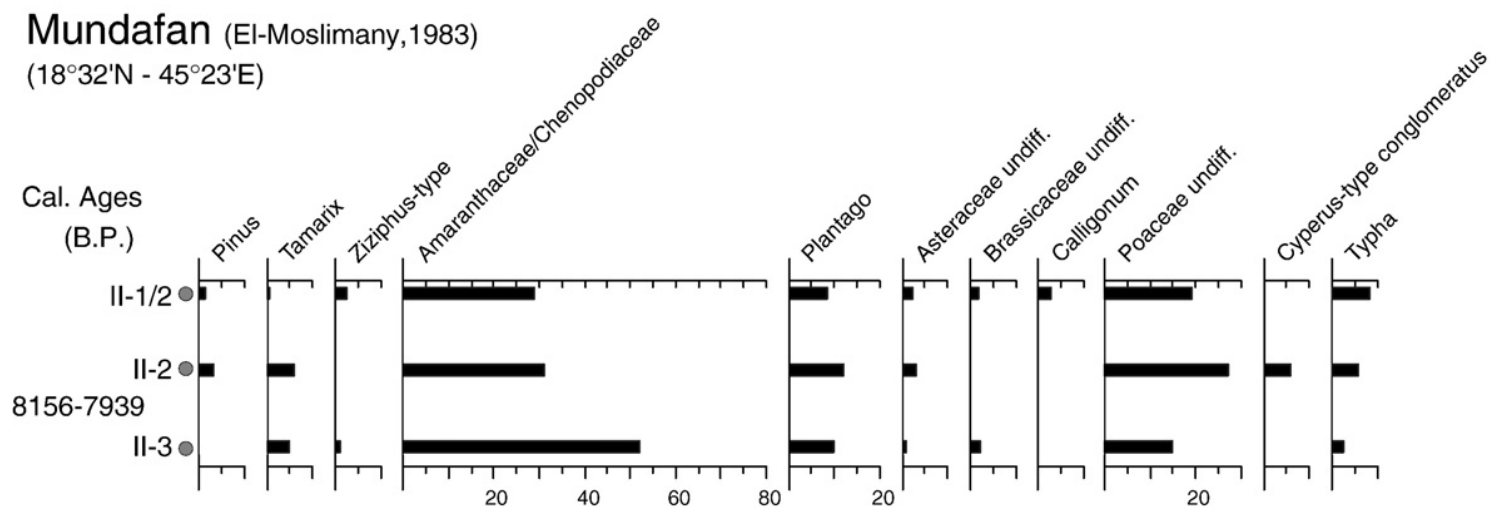

Fig. 8. Synthetic pollen diagram for Mundafan (Saudi Arabia), redrawn from El-Moslimany (1983). 


\section{Suwayh 1}
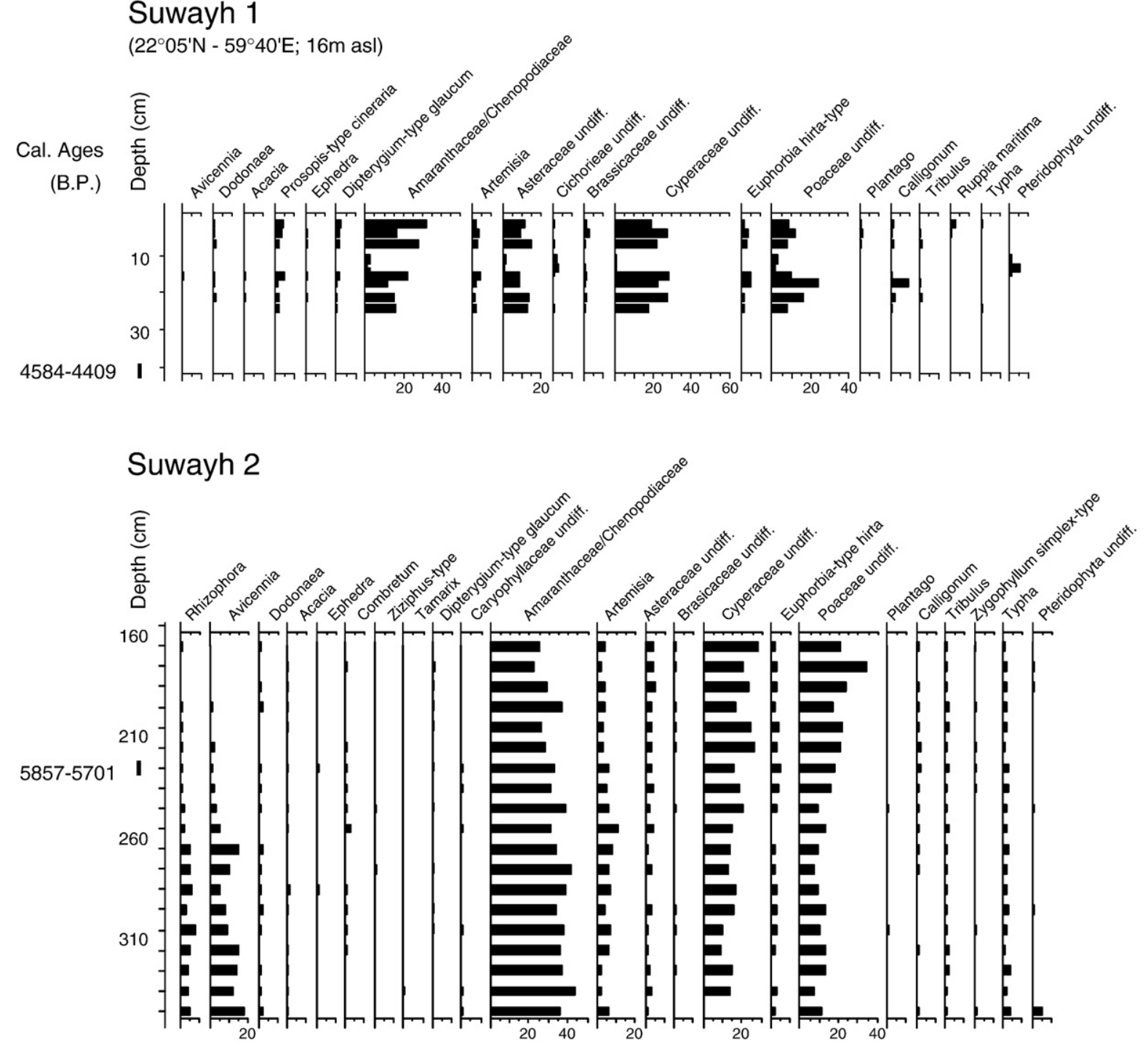

Fig. 9. Synthetic pollen diagram for Suwayh (Oman). No pollen was recorded in the intermediate levels between Suwayh 1 and 2 (redrawn from Lézine et al., 2002).

Oman and demonstrate that the Omano-Makranian influence prevailed at the time. This contradicts phytolith information, which suggests a possible tropical influence within the Poaceae species populations. The decrease in tree pollen percentages and correlative increase in Amaranthaceae/Cheonopodiaceae toward the top of the sequence record the progression of regional aridity. Similar pollen results were obtained from a stream section of Wadi Yudayah dated from about 5700 to $4500 \mathrm{cal}$ yr B.P. in the same area at slightly higher elevation ( $150 \mathrm{~m}$ ) by Garcia Anton and Sainz Ollero (1999), as well as in the archaeological site of Khor in Qatar around 7-6000 cal yr B.P. by Bonnefille and Riollet (1988), which shows that arid conditions very similar to modern ones prevailed during the mid-to late Holocene.

\subsection{The littoral of the Indian Ocean: the mangrove of Suwayh}

In contradiction with above continental pollen diagrams, the ancient mangrove of Suwayh near the littoral of the Indian Ocean $\left(22^{\circ} 05.289 \mathrm{~N}\right.$, $59^{\circ} 40.033 \mathrm{E}, 16 \mathrm{~m}$ asl) clearly records the influence of enhanced summer monsoon fluxes on the vegetation during the mid-Holocene (Lézine et al., 2002). Scattered stands of Avicennia marina occur today in Oman, on the northeast coast and along the Indian Ocean shore south of the
Masirah Island at $20^{\circ} 40 \mathrm{~N}$ as relict populations (Spalding et al., 1997). Suwayh records two well distinct periods (Fig. 10):

(1) An episode of mangrove development centred ca. 5700 cal yr B.P. is characterized by noticeable amounts in Avicennia (20\%) and Rhizophora (7\%). Avicennia is adapted to highly saline and evaporitic conditions and can survive far north of the tropics. Its northward occurrence is probably reached in the Sinai Peninsula at $28^{\circ} \mathrm{N}$. Rhizophora mucronata development requires more humid conditions and develops under rainy climate at the mouth of rivers where it benefits from dilute waters. Relict patches of Rhizophora are nowadays found in the southernmost part of the Peninsula at the Red Sea shore (Ghazanfar and Fisher, 1998). It is absent from the Omani coasts. Its development, together with the absence of Prosopis-type cineraria in the lowermost samples of Suwayh testify for strong tropical influence at the site location with the OmanoMakranian floristic province being displaced north.

(2) The upper levels of the core dated from the late Holocene record the dramatic fall in Avicennia percentages (less than 1\%) and the disappearance of Rhizophora. In addition to the development of Prosopis in the same levels, they record the 
At Awafi (Parker et al., 2004)

$\left(25^{\circ} 42^{\prime} 57 \mathrm{~N}-57^{\circ} 55^{\prime} 57 \mathrm{E}\right)$

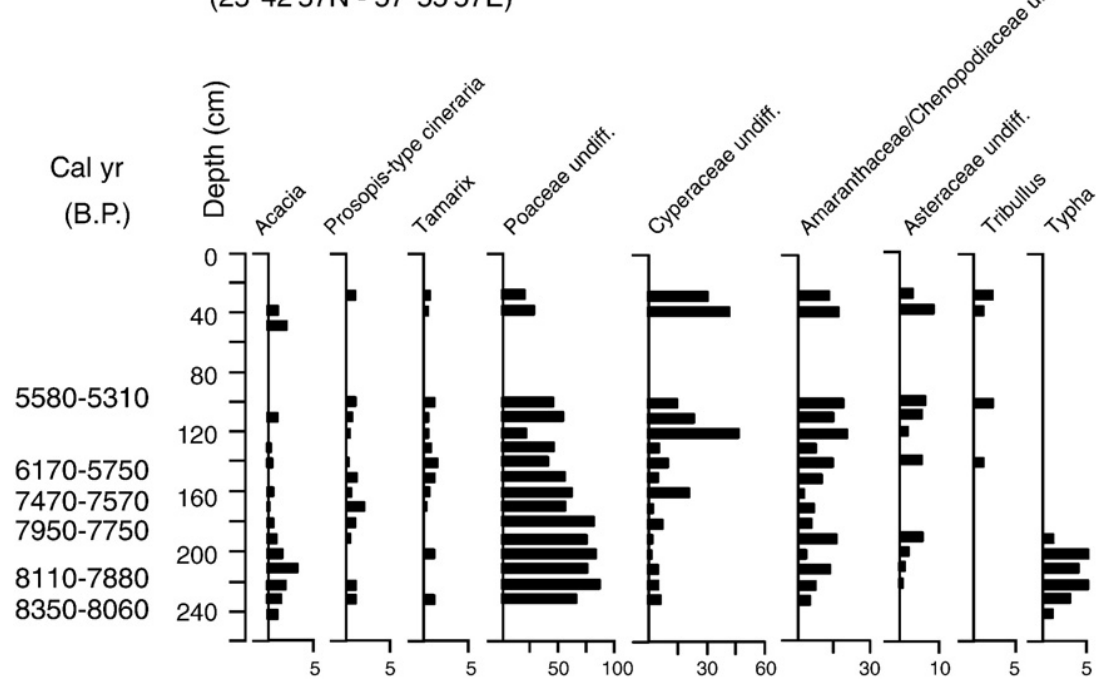

Fig. 10. Synthetic pollen diagram for At Awafi (Ras al-Rhaimah, UAE) redrawn from Parker et al. (2004).

setting of the modern conditions, i.e., the dominant OmanoMakranian influence at the core site.

\section{Phases of human occupation (Fig. 11)}

Most archaeological sites located in the desert areas appear as flint scatters, where some earths are occasionally found. In the desert lowlands, these are generally referred as "Rub' al-Khali Neolithic", and considered by most prehistorians as linked to a wetter phase, usually following McClure's (1976) suggestions. Four radiocarbon dates ranging from $9790 \mathrm{cal}$ yr B.P. to $8000 \mathrm{cal}$ yr B.P. were obtained from ashes or charcoal in hearths associated with surface scatters in the in the al-Hawa area, and another one at $7900 \mathrm{cal}$ yr B.P. from a hearth just below the surface of a stratified site at QWD-1 near Shabwa (Lézine et al., 1998). Despite the absence of any palaeoecological data all are considered as temporary campsites of small groups of huntergatherers. The flint industry includes arrowheads and scrapers. Grinders may attest to some plant processing (not necessary linked to agriculture), while fragments of axes of allochtonous green stone probably suggest movements between the desert and the highlands, probably already according to a pattern well attested later. Ashes from a hearth found ca. $1 \mathrm{~m}$ below present surface in the section of a small wadi at the piedmont of the Yemeni highlands (site MKH-26) have been dated around $9430 \mathrm{cal}$ yr B.P. (Cleuziou and Tosi, 1997). Earlier dates were obtain on the desert margins of Dhofar, from a surface site at Zebrit 68, dated $10380 \mathrm{cal}$ yr B.P. (Zarins, 2001), and stratified occupation level in the section of a wadi at Khabarut, dated between 10750 and $9840 \mathrm{cal} \mathrm{yr} \mathrm{B.P.} \mathrm{(Amirkhanov,} \mathrm{1994;} \mathrm{Zarins,} \mathrm{2001),} \mathrm{but}$ these were obtained from fresh-water shells and therefore have to be considered with care. The oldest date known from Arabia is around $10820 \mathrm{cal}$ yr B.P., from charcoal, in the section of Wadi Wattaya near Muscat in Oman (Uerpmann, 1992).

Our data is more consistent from 7500 cal yr B.P. onwards. It mainly comes from the coastal areas of the Persian Gulf and the Oman peninsula, where stratified sites are well preserved, most likely because their sedimentary components include a large number of shells. These coastal sites are settled in winter by small groups of 30-60 people dwelling in round huts, collecting shellfish and fishing in shallow waters and coastal lagoons. Such campsites are known from the Persian Gulf like Dosiriya and Abu Khamis in Saudi Arabia (Masry, 1974), Khor in Qatar (Inizan, 1988), Dalma and Marawah in the United Arab Emirates (Beech et al., 2005) and the Arabian Sea, RH-6 near Muscat (Biagi, 1985) or SWY-1 in the Ja'alan (Charpentier et al., 2003). They are considered to belong to a yearly pattern of mobility that includes spring campsites in the piedmontane areas and smaller summer ones in the mountains. A large spring gathering camp occupied between 7200 and 6300 cal yr B.P. (according to a set of 15 radiocarbon dates made on charcoal) is known at al-Buhais-18 in the Emirate of Sharjah (Uerpmann, 2003) that may be linked to the coastal settlements in the area of Umm al-Qaiwayn (Cleuziou, 2005). Meat consumption was almost exclusively from domesticated animals at al-Buhais. This confirms the occasional recovery of domesticates on the coastal winter sites (where the main food was fish) but also in the western Rub'al-Khali where domestic goat is present at Jiledah and al-Mutabthat (Edens, 1982) while domestic Bos taurus is also associated with lake deposits (McClure, 1978). As these domesticates are also found around $8000 \mathrm{cal} \mathrm{yr} \mathrm{B.P.} \mathrm{and} \mathrm{possibly} \mathrm{earlier}$ at ath-Thayyila in the Yemeni Highlands (Fedele, 1990), we may assume that human communities that practiced herding used to move between these highlands and the lacustrine areas, since $7500 \mathrm{cal} \mathrm{yr}$ B.P., and possibly much earlier. This would also fit with the many representations of large bovids in the rich rock-art of Yemen and western Saudi Arabia (Garcia et al., 1991).

Al-Buhais is abandoned before $6000 \mathrm{cal}$ yr B.P., and the excavators have recently advocated that all the desert areas were also abandoned by that time (Uerpmann, 2003). Populations concentrated along the Arabian sea coast, as attested by several dozens of sites such as RH-5 near Muscat (Biagi et al., 1984), Wadi Shab GAS-1 (Tosi and Usaï, 2003) many sites in the Ja'alan (Cleuziou, 2007) and the newly discovered site of Gihayu near Aden in Yemen (Rosello-Izquierdo et al., 2005) This may be too simplistic an interpretation. Archaeological studies on these sites still attest to a seasonal occupation in winter at and after the time of maximum development of mangroves, and display many relations with the interior. Interior sites are difficult to detect because lithic industries lack diagnostic types. Many undated flint scatters may belong to. We can assume that at least the highlands and the piedmontane valleys were still occupied, as attested in the Yemeni highlands near Dhamar (Edens and Wilkinson, 1998) or in the tributaries of the Wadi Hadramawt, in the region of Makaynun (5820 cal yr B.P. at HDOR 549) (Pa-2269, unpublished data), Wadi Shumliya (McCorriston et al., 2002), or near Shabwa (6745 cal yr B.P. at IRM-2, 6074 cal yr B.P. at Rushum Rumayd, 5485 cal yr B.P. at SH-84). This may have been a period of early irrigation agriculture in Yemen as documented by dams in the Dhamar region (Wilkinson, 2002) or in the Wadi Shumliya (Harrower, 2005; McCorriston and Oches, 2001). 

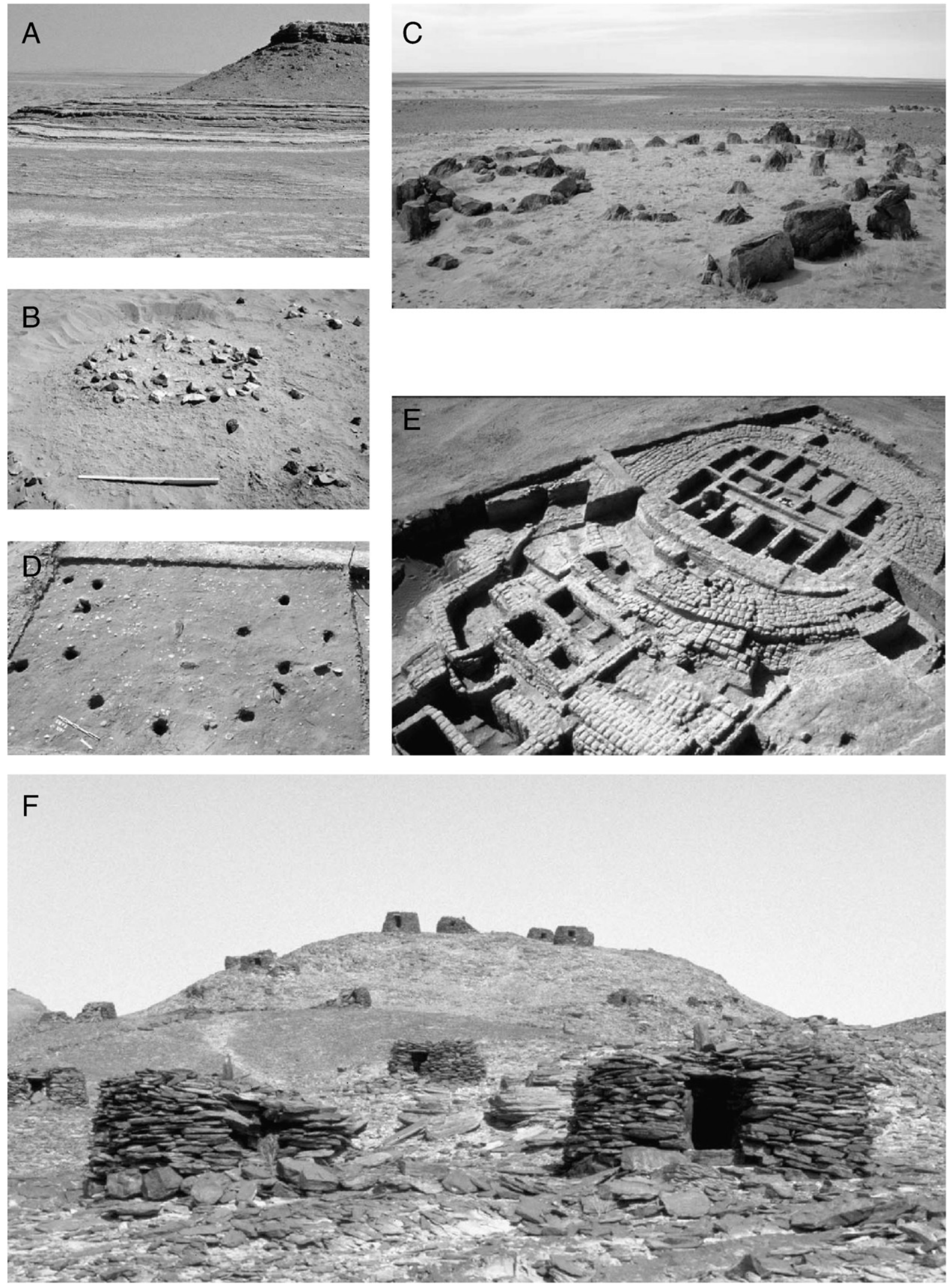

Fig. 11. (A) Lacustrine deposits of al-Hawa (Yemen): (B) hearth under excavation ABR-1 (Yemen), ca. 9570 cal yr B.P; (C) Early Bronze Ages houses (temporary?) at Jebel Thanniya, site ATH-8, near the former extension of al-Hawa palaeolake; (D) circular houses of temporary fishing campsite at SWY-2, Oman, ca. 6500 cal yr B.P; (E) Early Bronze Age mud brick tower of permanent agricultural oasis settlement at Hili 8, U.A.E. (5000-4000 cal yr B.P.); and (F) Early Bronze Age collective burials on Jebel Ruwayq, near the former extension of alHawa palaeolakes (F). 
By the very end of the 6th millennium B.P., oasis agriculture with date-palm gardens and cereal cultivation is well attested in the desert piedmonts of the Omani mountains, along the piedmontane sections of the main wadis. The typical site is Hili 8. It combines mudbrick houses and huge towers made of mudbrick associated with the gardens and an irrigation system of trenches tapping the water upstream from the underground water table of a wadi (Cleuziou, 1998). The two earliest dates recorded on the site come from two contemporaneous hearths associated with the construction of the tower which were both dated around $4970 \mathrm{cal}$ yr B.P. Many similar sites are known, like Bat where similar architecture was constructed in stone. In the Oman peninsula, the "Land of Magan" of Mesopotamian cuneiform tablets, displays a remarkable cultural unity throughout the 5th millennium B.P., combining coastal, mountainous and piedmontane areas (Cleuziou, 2003). The dead are placed in collective tower-like burials that mark the landscapes of settlements. Elsewhere, the presence of agricultural settlements, some of them with an urban aspect like Hammat al-Qa in the Dhamar basin of Yemen (Edens et al., 2000) is now obvious for the western highlands, while the 5th millennium cal B.P. presence in the lowlands is attested by tower-like burials known by the thousands in Yemen all along the Jawf-Hadramawt axis (Braemer et al., 2001). Dates ranging between 4820 and $4420 \mathrm{cal}$ yr B.P. were obtained from the bones of collective burials at Ruwayq and Jidran (Braemer et al., 2001). Villages associated with tower-like burials are known in the Wadi Hirab, a left side tributary of the Wadi al-Jawf (Cleuziou et al., 1992). A date at 4360 cal yr B.P. was obtained for site HDOR 415 (Pa-2270, unpublished data) in the Hadramawt, another one at $4770 \mathrm{cal}$ yr B.P from a sample in the most recent of a long sequence of hearths at IRM-2 in the Wadi Irmah (Gif-9489, unpublished results).

Although more studies are needed, there is some agreement on the importance of agriculture in the piedmont oases of Oman. Considering the similarity between ancient and modern geographical situations, we may assume that the irrigation system evidenced at Hili was used in other ancient oases, such as Bat or Bisyah. Data are even more elusive in Yemen. The large oasis of Mareb and its sophisticated irrigation system was probably developed during this period (Wagner, 1993) and the same is accepted for the Wadi Markha to the south (Brünner, 1997). These dates are still a matter of discussion. We may therefore conclude that during the 5th millennium B.P., irrigated agriculture was developed in the Arabian lowlands, based on various systems such as falaj (underground channels or permanent spring derivations) in Oman or sail (flood derivation) in Yemen.

\section{Discussion}

\subsection{Hydro-climatic conditions}

One of the most striking features of our paleohydrological records is the timing and the duration of the Arabian humid period. As shown on Fig. 12, the oxygen isotope and terrigenous record of core $74 \mathrm{KL}$ recovered off the Indian Ocean coast of the Arabian Peninsula (Sirocko et al., 1993) indicates that the climate evolution over the Northern Indian Ocean and the Arabian Peninsula was associated with the early Holocene rise in the summer insolation forcing of the Indian monsoon since about $16300 \mathrm{cal}$ yr B.P. However, this early beginning of the humid period is not documented on the continent except for two dates from the Rub' al-Khali paleolakes at 13400 and $15600 \mathrm{cal}$ yr B.P. (McClure, 1976). Significant monsoonal influence over the Arabian hinterland was delayed until the minimum of precession (Berger and Loutre, 1991) as a consequence of increased sea surface temperature and Northward heat transport from the adjacent Indian Ocean (Jung et al., 2004). The al-Hawa record suggests that the arid-humid transition

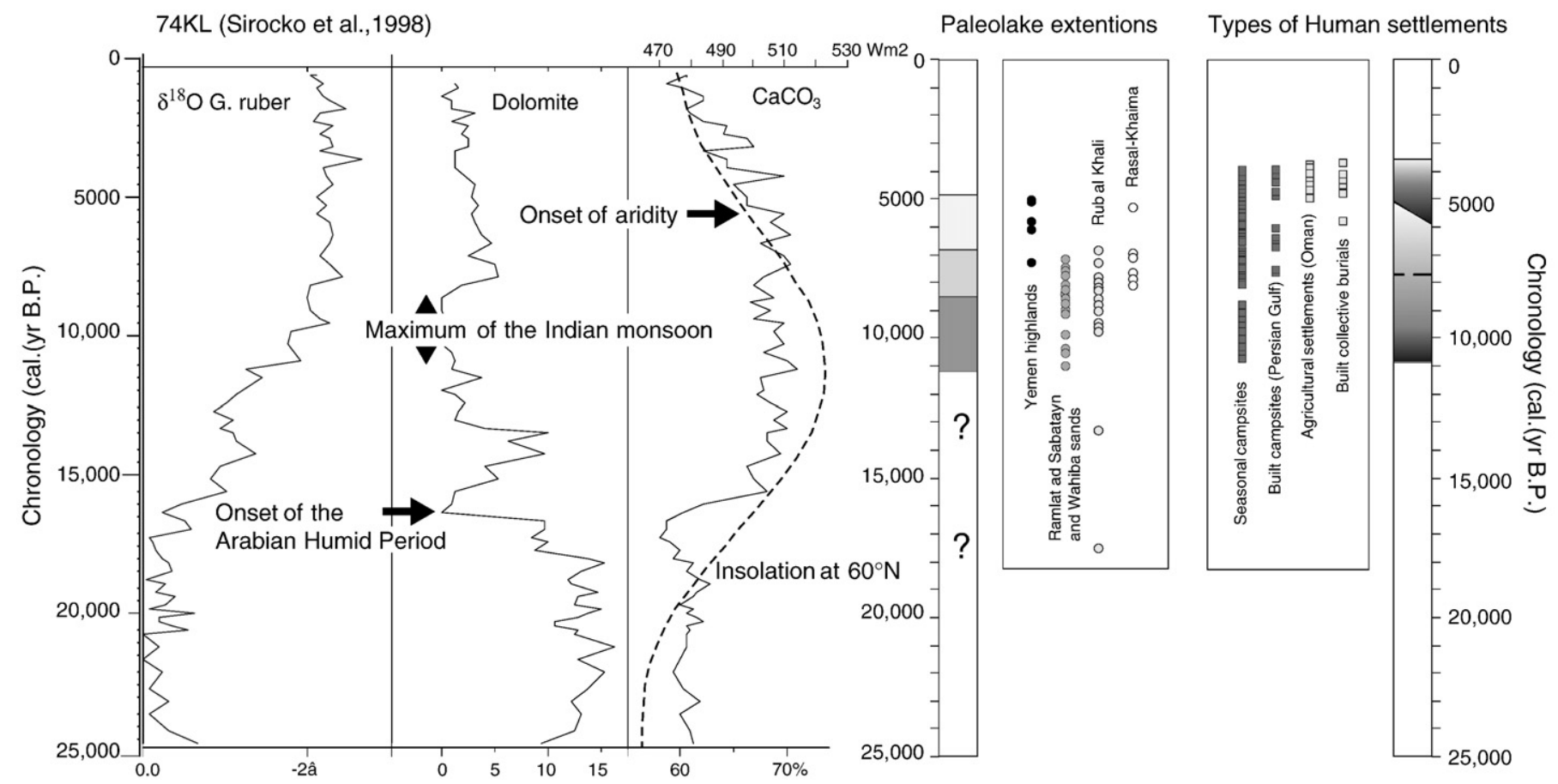

Fig. 12. Synthesis diagram relating geological and archaeological radiocarbon dates to the 74KL marine record of environment and climate changes over Arabia from 25 000 cal yr B.P. (Sirocko et al., 1993) to the present. Chronology is given in calendar years B.P. with zero equal to $1950 \mathrm{AD}$. The summer insolation curve at $60^{\circ} \mathrm{N}$ comes from Berger and Loutre (1991). Paleolake extensions are deduced from 42 14C measurements: from left to right: from the Yemen highlands (Rada and Saada); from the lowland deserts of Yemen (al-Hawa, Shabwa) and Oman (al-Haid); from the Rub' al-Khali (McClure, 1976); and from Ras al Khaima (Parker et al., 2004). Types of human settlements are deduced from 140 14C measurements from archaeological sites recovered from the littoral of the Indian Ocean to the South to the Persian Gulf to the North. Four main types are recognized: from left to right temporary camps made in light material (wood, etc.); "built" (stone based) camp sites (restricted to the Persian Gulf littoral area); and agricultural settlements built of stones and mud bricks, then cemeteries of stone tower graves with single or multiple chambers and collective rituals. Seasonal campsites are still used in South Arabian lowlands, whereas the disappearance of the built collective burials marks the end of the Early Bronze Age (as understood in this paper) and the raise of new forms of social complexity (Cleuziou, 2007) when aridity became well established regionally. 
occurred very rapidly, within centuries, at about $11000 \mathrm{cal}$ yr B.P., and agrees well with paleohydrological reconstructions based on a U/Th speleothem record from Oman (Fleitman et al., 2003).

The 14C ages on lacustrine sediments from the lowland deserts of Yemen, Oman and Saudi Arabia demonstrate that the maximum of the Arabian humid period lasted to 7000 cal yr B.P. a date consistent with the orbitally-induced maximum activity of the Indian summer monsoon (Sirocko et al., 1993). Its termination is not precisely documented, due to the impact and possible removal of sediments by erosional processes in a predominantly arid environment. However, the concordance of the data from al-Haid (Oman), al-Hawa and Shabwa (Yemen) and the Rub' al-Khali (Saudi Arabia) tends to suggest that the humid period ended simultaneously throughout the Southern Arabian lowlands. However, recent studies carried out in the Wahiba Sands (Radies et al., 2005) and at At Awafi by Parker et al. (2004) yielded a more recent age (5500 and $5300 \mathrm{cal}$ yr B.P., respectively) for the last occurrence of lacustrine extension in the lowlands. It is probable that, during the late Holocene, monsoon rains occurred only intermittently, responsible for local fresh-water extensions. In the highlands, summer monsoon fluxes remained important later, up to at least 5000 cal yr B.P., allowing for lakes which took place during the early Holocene (Wilkinson, 2005) to extend. River flood deposits which are widely distributed along wadis at the back slopes of the highlands of Yemen (e.g., Coque-Delhuile and Gentelle, 1995) also testify for seasonal rainfall in mountains during the Late Holocene. Monsoon rains were however not strong enough to pass through the highlands and reach the inland deserts of Ramlat asSab'atayn and Rub' al-Khali.

The marine records of the end of the Arabian Humid Period, which integrate all these regional patterns, show a gradual trend toward dry conditions, associated with the progressive decline of summer insolation and related convection forced by the surrounding highlands (Berger and Loutre, 1991). Core 74KL does not record any abrupt humid-arid transition (Sirocko et al., 1993), contrary to that observed off West Tropical Africa at 5500 cal yr B.P. (deMenocal et al., 2000). In a recent paper, Gupta et al. (2003) confirms that the upwelling intensity linked to summer monsoon circulation over the Northern Indian Ocean smoothly declined from the early Holocene to the present, confirming the Omani speleothem record (Fleitman et al., 2003).

During the Arabian Humid Period, the lowlands underwent large amplitude hydrological changes as depicted by the phases of lake level lowering or of complete lake dessication at al-Hawa, which occurred around 10300,8750 and 7900 cal yr B.P. These were coeval, within the radiocarbon age uncertainties, with phases of reduced upwelling intensity in the Northern Indian Ocean (Gupta et al., 2003), thus recording phases of weak monsoon fluxes over the whole area. Similar records of Holocene hydrological change have been recorded elsewhere in the area influenced by the Indian monsoon system (Hong et al., 2005). The correlation between the timing of these weak Indian summer monsoon events and the phases of cooling in the North Atlantic (Bond et al., 1997) suggests strong links between the low and the north latitude climate systems.

\subsection{The vegetation landscape}

Except in the littoral zone of the Indian Ocean, at Suwayh, the vegetation landscape of the Arabian lowlands did not change considerably and remained of desert/semi-desert type throughout Holocene period. Tropical summer precipitation wind belts influenced the inland desert of Yemen during the early to mid-Holocene as shown by the permanency of Somalia-Masaï tree populations. This influence extended toward the East to $59^{\circ} 40 \mathrm{E}$ at Suwayh, at least until $5700 \mathrm{cal}$ yr B.P., explaining the development of Rhizophora mangrove stands. More surprising is the pollen content of the Rub' al-Khali paleolake sediments, which records a vegetation landscape drastically different from that of today and without any indication of tropical plant assemblages. This has to be considered with a certain caution because of the scarcity of data (only three samples from the Mundafan paleolake). At At Awafi, the dominance of Prosopis cineraria, which is one of the main components of the Omano-Makranian phytogeographical zone, leads to consider the dominant influence of winter rains, as nowadays, near the Persian Gulf. This seems to contradict authors' assumptions concerning the probable presence of tropical Poaceae, almost from 8500 to 5900 cal yr B.P.

It is clear that, from the review presented here that the Arabian desert was not as "green" as the Saharan desert at any period of the Holocene.

\subsection{Relations between man and environment}

Most prehistorians assume that Arabia was empty until 10000 B.P. (Amirkhanov, 1994; McClure, 1994), a period even characterized by Uerpmann (Uerpmann, 1992) as the "Early Holocene empty quarter". The dated earliest occupations from the al-Hawa area come significantly later than the earliest filling of the lake, between the first and the second phase of drying, but considering the current state of research, we can only say that we know nothing, not that there was no one there. Site ABR-1, dated from 8000 cal yr B.P., lay on a burnt surface that may correspond to the first episode of lake level lowering dated from $10300 \mathrm{cal} \mathrm{yr}$ B.P. or later $(8750 \mathrm{cal} \mathrm{yr}$ B.P. $)$. It would however be misleading to think in terms of a vertical stratigraphy. As people lived on the side of the lake, the occurrence of ABR-1 in the central area of the depression confirms that the lake had almost disappeared by that time. With the possible exception of some earlier elevations, the archaeological evidence is therefore spatially distributed according to the changing extension of the lake. A better understanding of lakeside occupations would need a program of precise spatial documentation using geographic information science including altimetry and radiocarbon dating of a sufficient number of sites. Small human groups had a migratory pattern between the highlands in summer and the lowlands in winter, following the riverine corridors. The important herbaceous cover around the freshwater lakes was probably enough to support wild animals but also small flocks of bovids and goats. Phases of drastic dryness such as those recorded at al-Hawa, did not disrupt this pattern, one that must have continued for a rather long time after the end of the wet phase, considering the example of al-Buhais in Oman (Uerpmann, 2003). Small human groups with their domestic animals could adapt to drier conditions by exploiting still-favourable areas. As suggested by Close (1992), bovids do not dig wells, but humans can do it for them, and obtain in return potable liquids such as milk and blood.

The highly developed coastal adaptation in Oman is one part (the only known) of this same pattern, and rather than being a refuge area as assumed by Uerpmann (2003). Coastal sites belong to a system of growing adaptative technical and social developments. Those encompassed intensification in the exploitation of all possible niches in an environment that was more discontinuous than before in terms of vegetation and resource distribution. Early forms of agriculture may arise, although this is still a pending question. Agriculture is now well attested before the 5th millennium B.P. (Ekstrom and Edens, 2003) in the Highlands of Yemen and Wilkinson (2002) has tagged the question of an African rather than Near Eeastern origin, according to the possible presence of Sorghum. Sorghum has already been reported in the Middle 5th millennium B.P. in Yemen from grain imprints on pottery by Costantini (Costantini, 1990) and for the same period in Oman at Hili 8 (Cleuziou and Costantini, 1980). The possible early irrigation systems suggested during the 7th-6th millennia B.P. for the Wadi Shumliya area in the Hadramawt (Harrower, 2005; McCorriston and Oches, 2001) may well fit into this picture.

By $5000 \mathrm{cal}$ yr B.P. onwards, these developments led to the irrigated agricultural systems of the Early Bronze Age, well documented in Oman and only ascertained in lesser known piedmontane Yemen. As demonstrated in Oman, exchanges among the various ecological niches were very important, and historical conditions may also have played a role 
(Cleuziou, 2003). From what is known by the presence of 5th millennium B.P. burials at places such as Ruwayq and Jidran and possible settlements such as ATH-7 near Jebel ath-Thaniyyah (Braemer, unpublished results), these agro-pastoral developments are also present until the Late Holocene, in what is at present the Ramlat as-Sab'atayn desert. Only with the obvious absence of South Arabic settlement, by 3500 cal yr B.P., can we be sure that the desert was abandoned.

\section{Conclusion}

The review presented here illustrates the role of the peculiar geomorphological features of Southern Arabia in the record of past climate changes and their impact on the lowland desert landscapes. Enhanced monsoon fluxes led to the extension of several paleolakes in the lowlands from 11000 to $5000 \mathrm{cal}$ yr B.P. and the eastward displacement of the tropical phytogeographical zone of influence. However, paleolake records are surprisingly scarce and the two main fresh-water extensions at Mundafan in Saudi Arabia (McClure, 1976) and at al-Hawa in Yemen (Lézine et al., 1998, 2007) were primarily linked to intense surface run-off from the adjacent Yemen highlands. At the easternmost edge of the desert, the recently studied paleolake of At Awafi (Parker et al., 2004) also benefited from run-off from the Omani highlands but also from high groundwater level in relation with the proximity of the sea. The presence of the Yemen highlands and Hadramawt plateaus which acted as topographical and ecological barriers against the northward penetration of tropical plants (as observed in the Saharan desert at the time) and the permanence of strong evaporation played a determinant role in the vegetation composition which remained of desert, semi-desert type throughout the Arabian Humid Period.

Adaptation to such an environment marked by recurrent phases of intense dryness is key understanding the development of human communities in the Arabian lowlands. The environment constrains seasonal mobility across various ecosystems according to the seasonality in rainfall. Such mobility is recorded as early as the 8th millennium B.P., at least in Oman. Small human groups, splitting or merging according to the season and the quantity of available resources followed lines of freshwater points (temporary water courses and fluctuating lake shores). Data suggest that these groups were well adapted and probably small enough to survive phases of dryness. The al-Hawa area, in the inland desert of Yemen, is probably one of the few places were such a pattern can be studied, on the model of research by Hoelzmann et al. (2001) in the west Nubian paleolakes area in Sudan. The archaeological record still awaits detailed study. We would like to suggest that at the time of increasing aridity, after 7000 cal yr B.P., humans tried to maintain this lifestyle, using the remaining water resources and gradually developing them where it was possible. This could not be done without more "action" on landscape, meaning work investments (irrigation systems) in the exploited territories, more manpower, and deep social changes accompanying land tenure that characterized the beginning of the Early Bronze Age (5th millennium B.P.). These societies were successful but were also vulnerable to any kind of social crisis or natural disruption. In other words, the link between man and water and through it between man and climate is obvious, but the linkages engage complex social mechanisms in nonlinear, non-binary relationships.

\section{Acknowledgements}

Thanks are due to I. N. Al-Ganad (Geological Survey and Mineral Resources Board, Sana'a), Y. Abdallah, A. Shamsan, A. H. Al-Herf and S.H. Sadek (General Agency of Antiquities, Museums and Manuscripts, Yemen), F. Mermier and F. Burgat (CERFAS, Sana'a) in Yemen, J.-P. Breton (BRGM), B. Al-Sabri, A. Al-Shanfari (Department of Antiquities, Ministry of Heritage and Culture, Muscat), H. bin Mohammed Al-Azri (General of Minerals, Ministry of Commerce and Industry, Muscat) and H. David in Oman, for field assistance and authorizations, F. Aptel, J.-P.
Cazet (CNRS-Gif), D. Malengros, P. Recourt (CNRS-Lille) and P. Tremblay (CNRS-Marseille) for laboratory assistance. Anonymous reviewers are warmly acknowledged for improvements on the manuscript. AMS dating was provided by NSF Arizona (USA) and UMS-ARTEMIS (France) AMS facilities. This work was supported by French CNRS grants through "Variente" and "Eclipse" programmes. Data are available from the first author and through the Eclipse programme Web page (http://medias. obs-mip.fr/eclipse). LSCE contribution no. 1831.

\section{References}

Amirkhanov, H., 1994. Research on the Palaeolithic and Neolithic of the Hadramawt and Mahra. Arabian Archaeol. Epigr. 5, 217-232.

Aqrawi, A.A.M., 2001. Stratigraphic signatures of climatic change during the Holocene evolution of the Tigris-Euphrates delta, Mesopotamia. Glob. Planet. Ch. 28, 267-283.

Beech, M., Cuttler, R., Moscrop, D., Kallweit, H., Martin, J., 2005. New evidence for the Neolithic settlement of Marawah Island, Abu Dhabi, United Arab Emirates. Proc. Sem. Arab. Studies 35, 37-56.

Berger, A., Loutre, M.-F., 1991. Insolation values for the climate of the last 10 million years. Quatern. Sci. Rev. 10, 297-317.

Biagi, P., 1985. Excavation of the aceramic shell-midden of RH6, Qurm, Muscat. East West 35 (4), 410-415.

Biagi, Torke, W., Tosi, M., Uerpmann, H.-P., 1984. Qurum, a case study of coastal archaeology in Northern Oman. World Archaeol. 16 (1), 43-61.

Bond, G., Showers, W., Cheseby, M., Lotti, R., Almasi, P., deMenocal, P., Priore, P., Cullen, H., Hajdas, I., Bonani, G., 1997. A pervasive millennial-scale cycle in North Atlantic Holocene and glacial climates. Science 278, 1257-1266.

Bonnefille, R., Riollet, G., 1980. Pollens des savanes d'Afrique orientale. CNRS, Paris.

Bonnefille, R., Riollet, G., 1988. Palynologie des sédiments holocènes de sites archéologiques de Qater. In: Inizan, M. (Ed.), Recherche sur les Civilisations. Préhistoire à Qatar, Paris, pp. 137-146.

Braemer, F., Steimer-Herbet, T., Buchet, L., Saliège, J.-F., Guy, H., 2001. Le Bronze ancien du Ramlat as-Sabatayn (Yémen). Deux nécropoles de la première moitié du IIIe millénaire à la bordure du désert: Jebel Jidran et Jebel Ruwaiq. Paléorient 27, 21-44.

Brünner, U., 1997. Geography and human settlements in ancient Southern Arabia. Arabian Archaeol. Epigr. 8, 190-202.

Chamley, H., 1989. Clay Sedimentology. Springer-Verlag, Berlin.

Charpentier, V., Angelluci, D., Méry, S., Saliège, J.-F., 2000. Autour de la mangrove morte de Suqayh, l'habitat Vie millénaire de Suwayh-11 (Ja'alan). Proc. Sem. Arab. Studies 30, 69-85.

Charpentier, V., Marquis, P., Pellé, E., 2003. La nécropole et les derniers horizons Ve millénaire du site de Gorbat al-Mahar (Suwayh SWY-1, Sultanat d'Oman): premiers résultats. Proc. Sem. Arab. Studies 33, 11-19.

Cleuziou, S., 1998. Early Bronze Age oasis life in the Oman Peninsula. In: Pearce, M., Tosi, M. (Eds.), Papers from the EAA Third Annual Meeting at Ravenna, 1997. Pre- and Protohistory. International Series, vol. I. BAR, Oxford, pp. 59-70.

Cleuziou, S., 2003. Early Bronze Age trade in the Gulf and the Arabian Sea: the society behind the boats. In: Potts, D.T., al-Naboodah, H., Hellyer, P. (Eds.), Archaeology in the United Arab Emirates. Trident Press, Londres, pp. 133-149.

Cleuziou, S., 2005. Pourquoi si tard? Nous avons pris un autre chemin. L'Arabie des chasseurs-cueilleurs de l'Holocène au début de l'Age du Bronze. In: Guilaine, J. (Ed.), Aux marges des grands foyers du Néolithique: périphéries débitrices ou créatrices? Errance, Paris, pp. 123-148.

Cleuziou, S., 2007. Evolution towards complexity in a coastal desert environment: early bronze age in the Ja'laan, Sulatant of Oman. In: Kohler, T, Van der Leeuw, S.E. (Eds.), Modelling longterm cultural changes. pp. 213-231. New York Univ. Press.

Cleuziou, S., Costantini, L., 1980. Premiers éléments sur l'agriculture protohistorique de l'Arabie Orientale. Paléorient 6 (2), 255-261.

Cleuziou, S., Inizan, M.-L., Marcolongo, B., 1992. Le peuplement pré-et protohistorique du système fluviatile fossile du Jawf-Hadramawt au Yémen. Paléorient 18 (1), 2-29.

Cleuziou, S., Tosi, M., 1997. Hommes, climats et environnements de la Peninsule arabique a l'Holocène. Paleorient 23 (2) 121-35121-35.

Close, A., 1992. The beginnings of food production in the Eastern Sahara. In: Gebauer, A.B., Price, T.D. (Eds.), Transitions to Agriculture in Prehistory. Prehistory Press, Madison, pp. 63-72.

Coque-Delhuile, B., Gentelle, P., 1995. Le Yémen aride, l'environnement du Quaternaire à l'Actuel. Sécheresse 6, 65-75.

Costantini, L., 1990. Ecology and farming of the protohistoric communities in the Central Yemeni Highlands. In: de Maigret, A. (Ed.), The Bronze Age Culture of Hawlân at-Tiyâl and al-Hadâ (Republic of Yemen). IsMEO, Rome, pp. 187-204.

deMenocal, P., Ortiz, J., Guilderson, T., Adkins, J., Sarnthein, M., Baker, L., Yarusinsky, M., 2000. Abrupt onset and termination of the African Humid Period: rapid climate responses to gradual insolation forcing. Quatern. Sci. Rev. 19, 347-361.

Edens, C. 1982. Towards a definition of the Rub'al-Khali "Neolithic". Atlal 6, 109-124.

Edens, C., Wilkinson, T.J., 1998. Southwest Arabia during the Holocene: recent archaelogical developments. J. World Prehist. 121, 55-119.

Edens, C., Wilkinson, T.J., Barratt, G., 2000. Hammat-al Qa and the root of urbanism in SW Arabia. Antiquity 74 (286), 854-862.

Ehrlich, A., 1995. Atlas of the inland-water diatom flora of Israel. Geological Survey of Israel. Israel Academy of Sciences and Humanities, Jerusalem.

Ekstrom, H., Edens, C.M., 2003. Protohistoric Agriculture in Highland Yemen: New Results from Dhamar. Yemen Update 45, 23-35. 
El-Ghazali, G.A., 1991. Pollen flora of Qatar. Scientific and Applied Research Centre. University of Qatar, Doha.

El-Ghazaly, G.E.B., 1993. A study on the pollen flora of Sudan. Rev. Palaeobot. Palynol. 76, 99-345.

El-Moslimany, A.P., 1983, History of Climate and vegetation in the Eastern Mediterranean and the Middle East from the Pleniglacial to the Mid-Holocene. Thesis, University of Washington.

El-Sayed, M.I., 1999. Sedimentological characteristics and morphology of the aeolian sand dunes in the eastern part of the UAE: a case study from Ar Rub' Al Khali. Sediment. Geol. 123, 219-238.

Faegri, K., Iversen, J., 1975. Textbook of pollen analysis, 3rd ed. Blackwell, Oxford.

Fagel, N., Debrabant, P., de Menocal, P., Demoulin, P., 1992. Utilisation des minéraux sédimentaires argileux pour la reconstitution des variations paléoclimatiques à court terme en mer d'Arabie. Oceanol. Acta 15, 125-136.

Fedele, F., 1990. Man, land and climate: emerging interactions from the Holocene of the Yemen Highlands. In: Bottema, S., Entjes-Nieborg, G., Van Zeist, W. (Eds.), Man's Role in the Shaping of the Eastern Mediterranean Landscape. Balkema, Rotterdam, pp. 31-42.

Fleitman, D., Burns, S.J., Mudelsee, M., Neff, U., Kramers, J., Mangini, A., Matter, A., 2003. Holocene forcing of the Indian monsoon recorded in a stalagmite from Southern Oman. Science 300, 1737-1739.

Garcia Anton, M., Sainz Ollero, H., 1999. Etude palynologique menée dans le secteur de Mleiha. In: Mouton, M. (Ed.), Mleiha 1. : Environements, stratégies de subsistence et artisanats., vol. 29. Trav. Maison Orient Méditerranéen, Lyon, pp. 83-87.

Garcia, M., Rashad, M., Hadjouis, D., Inizan, M.-L., Fontugne, M., 1991. Découvertes préhistoriques au Yémen. Le contexte archéologique de l'art rupestre de la région de Saada. CR. Acad. Sci. Paris 313 (série II), 1201-1206.

Gasse, F., 1986. Diatom assemblages in East Africa: classification, distribution and ecology. Rev. Hydrobiol. Trop. 16, 3-34.

Germain, H. 1981. Flore des Diatomées. Diatomo-phycées eaux douces et saumâtres du Massif Armoricain et des contrées voisines d'Europe occidentale. Soc. Nouv. Ed Boubée, Coll."Faunes et Flores actuelles", Paris.

Ghazanfar, S.A., Fisher, M., 1998. Vegetation of the Arabian Peninsula. Geobot 25, 1-362.

Gupta, A.K., Anderson, D.M., Overpeck, J.T., 2003. Abrupt changes in the Asian southwest monsoon during the Holocene and their links to the North Atlantic Ocean. Nature 421, 354-357.

Harrower, M.J., 2005. Environmental versus social parameters, ladscape, and the origins if irrigation in Southwest Arabia (Yemen). Thesis, University of Colombus.

Hoelzmann, P., Keding, B., Berke, H., Kröpelin, S., Kruse, H.-J., 2001. Environmental change and archaeology: lake evolution and human occupation in the Eastern Sahara during the Holocene. Palaeogeogr. Palaeoclim. Palaeoecol. 169, 193-217.

Holtzapffel, T., 1985. Les minéraux argileux: préparation, analyse diffractométrique et determination. Soc. Géol. Nord 12,1-136.

Hong, Y.T. Hong, B., Lin, Q.H., Shibata, Y., Hirota, M., Zhu, Y.X., Leng, X.T., Wang, Y., Wang, H., Yi, L., 2005. Inverse phase oscillations between the East Asian and Indian Ocean summer monsoons during the last 12000 years and paleo-El Niño. Earth Planet. Sci. Let. 231, 337-346.

Inizan, M.-L. (Ed.), 1988. Préhistoire à Qatar, Mission archéologique française à Qatar. ERC, Paris.

Inizan, M.-L., Lézine, A.-M., Marcolongo, B., Saliège, J.-F., Robert, C., Werthz, F., 1998. Paléolacs et peuplements holocènes du Yémen: le Ramlat As-Sabat'ayn. Paléorient 23, 137-149.

Jung, S.J.A., Davies, G.R., Ganssen, G.M., Kroon, D., 2004. Stepwise Holocene aridification in NE Africa deduced from dust-borne radiogenic isotope records. Earth Planet. Sci. Lett. 221, 27-37.

Krammer, K., Lange-Bertalot, H., 1986-1991. Bacillariophyceae. 1-4. Süsswasserflora von Mitteleuropa. Gustav Fischer Verlag, Stuttgart, New York.

Lézine, A.-M., Saliège, J.-F., Mathieu, R., Tagliatela, T.L., Mery, S., Charpentier, V., Cleuziou, S. 2002. Mangroves of Oman during the late Holocene: climatic implications and impact on human settlements. Veget. Hist. Archaeobot. 11, 221-232.

Lézine, A.-M., Saliège, J.-F., Robert, C., Werthz, F., Inizan, M.-L., 1998. Holocene lakes from Ramlat-asSab'atayn (Yemen) illustrate the impact of monsoon activity in Southern Arabia. Quatern. Res. 50, 290-299.

Lézine, A.-M., Tiercelin, J.-J., Robert, C., Saliège, J.-F., Cleuziou, S., Inizan, M.-L., Braemer, F., 2007. Centennial to millennial-scale variability of the Indian monsoon during the early Holocene from a sediment, pollen and isotope record from the desert of Yemen. Palaeogeogr. Palaeoclim. Palaeoecol. 243, 235-249.

Masry, A.H., 1974. Prehistory in Northeastern Arabia, the problem of interregional interaction. Field Research Projects. Coconut Grove, Miami.

McClure, H.A., 1976. Radiocarbon chronology of late Quaternary lakes in the Arabian Desert. Nature 263, 755-756.
McClure, H.A., 1978. Ar Rub' al Khali. In: Zötl, J.G., al-Sayari, S.S. (Eds.), Quaternary Period in Saudi Arabia, pp. 252-263.

McClure, H.A., 1994. A new Arabian stone tool assemblage and notes on the Aterian industry of North Africa. Arab. Archaeol. Epigr. 5, 1-16.

McCorriston, J., Oches, E.A., 2001. Two Early Holocene check dams from Southern Arabia. Antiquity 75, 675-676.

McCorriston, J., Oches, E.A., Walter, D.E., Cole, K.L., 2002. Holocene paleoecology and prehistory in highland southern Arabia. Paléorient 28, 61-88.

Parker, A.G., Eckersley, L., Smith, A.M., Goudie, A.S., Ward, S., White, K., Hodson, M.J., 2004 Holocene vegetation dynamics in the northeastern Rub' al-Khali desert, Arabia Peninsula: a phytolith, pollen and carbon isotope study. J. Quatern. Sci. 19, 665-676.

Petit-Maire, N., Page, N., Marchand, J., 1993. The Sahara in the Holocene. Map 1: 5000000. CNRS, Marseille.

Preusser, F., Radies, D., Driehorst, F., Matter, A., 2005. Late Quaternary history of the coastal Wahiba Sands, Sultanate of Oman. J. Quatern. Sci. 20, 395-405.

Radies, D., Hasiotis, S.T., Preusser, F., Neubert, E., Matter, A., 2005. Paleoclimatic significance of Early Holocene faunal assemblages in wet interdune deposits of the Wahiba Sand Sea, Sultanate of Oman. J. Arid Environ. 62, 109-125.

Reimer, P.J., Baillie, M.G.L., Bard, E., Bayliss, A., Beck, J.W., Bertrand, C., Blackwell, P.G. Buck, C.E. Burr, G. Cutler, K.B. Damon, P.E. Edwards, R.L. Fairbanks, R.G, Friedrich, M., Guilderson, T.P., Hughen, K.A., Kromer, B., McCormac, F.G., Manning, S., Bronk Ramsey, C., Reimer, R.W., Remmele, S., Southon, J.R., Stuiver, M., Talamo, S., Taylor, F.W., van der Plicht, J., Weyhenmeyer, C.E., 2004. IntCal04 terrestrial radiocarbon age calibration, 0-26 cal kyr BP. Radiocarbon 46, 1029-1058.

Rosello-Izquierdo, E., Morales-Muniz, A., Popov, S.V., 2005. Gihayu: a Late Stone Age fishing station in the coast of Yemen. Paleorient 31 (1), 116-125.

Saliège, J.F., Lézine, A.-M., Cleuziou, S., 2005. Estimation de l'effet réservoir 14C marin en mer d'Arabie. Paléorient 31 (1), 64-69.

Simonsen, R., 1987. Atlas and Catalogue of the Diatom Types of Friedrich Hustedt, vol. 1-3. Cramer, Berlin.

Sirocko, F., Lange, H., 2001. Clay-mineral accumulation rates in the Arabian Sea during the late Quaternary. Marine Geol. 97, 105-119.

Sirocko, F., Sarthein, M., Erlenkeuser, H., Lange, H., Arnold, M., Duplessy, J.-C., 1993. Centuryscale events in monsoonal climate over the past 24,000 years. Nature 364, 322-324.

Spalding, M., Blasco, F., Field, C., 1997. World Mangrove Atlas. The International Society for Mangrove Ecosystems, Okinawa, Japan. $178 \mathrm{pp}$

Stabel, H.H., 1986. Calcite precipitation in Lake Constance: chemical equilibrium, sedimentation, and nucleation by algae. Limnol. Oceanogr. 31, 1081-1093.

Sylvestre, F., 1997. La dernière transition glaciaire-interglaciaire (18 000-8 00014 C ans BP) des Andes tropicales sud (Bolivie) d'après l'étude des diatomées. Thesis Muséum National d'Histoire Naturelle, Paris.

Sylvestre, F., Servant-Vildary, S., Roux, M., 2001. A diatom-based ionic composition and salinity models for paleoclimatic inferences from Bolivian Altiplano. J. Paleolimnol. 25, 279-295.

Talbot, M.R., Allen, P.A., 1996. Lakes. In: Reading, M.G. (Ed.), Sedimentary Environments. Blackwell, London, pp. 83-124.

Tosi, M., Usaï, D., 2003. Preliminary report on the excavations at Wadi Shab, area 1, Sultanate of Oman. Arab. Archaeol. Epigr. 14 (1), 8-23.

Uerpmann, M., 1992. Structuring the Late Stone Age of Southern Arabia. Arab. Archaeol. Epigr. 3, 65-109.

Uerpmann, M., 2003. The Dark Millennium-remarks in the final Stone Age in the Emirates and Oman. In: Potts, D.T., al-Naboodah, H., Hellyer, P. (Eds.), Archaeology in the United Arab Emirates. Trident Press, London, pp. 74-81.

Uerpmann, M., Uerpmann, H.P., Jassim, S.A., 2000. Stone Age nomadism in SE-Arabia: paleo-economic considerations on the Neolithic site of al-Buhais 18 in the Emirate of Sharjah, U.A.E. Proc. Sem. Arab. Studies 30, 229-234.

Wagner, W., 1993. Antike Technologie-die sabäische Wasserwirtschaft von Marib. Teil 2: bodenkundliche Untersuchungen in der Oase Marib. Deutsches Archäologisches Institut San'a', Archäologische Berichte aus dem Yemen, Band VI. Philipp von Zabern, Mayence.

Weaver, C.E., 1989. Clays, Muds, and Shales. Elsevier, Amsterdam.

Wilkinson, T.J., 2002. Project for the archaeology of Yemeni terraced agriculture, 2001-2002 annual report.

Wilkinson, T.J., 2005. Soil erosion and valley fills in the Yemen highlands and Southern Turkey: integrating settlement, geoarchaeology, and climate change. Geoarchaeology 20 (2), 169-192.

Wood, J., 1997. A handbook of the Yemen flora. Royal Botanic Garden, Kew.

Zarins, J. 2001. The Land of Incense, Archaeological Work in the Governorate of Dhofar, Sultanate of Oman, 1990-1995. Archaeology and Cultural Heritage Series. Sultan Qaboos University Publications, Muscate. 